\title{
The wolf spider genus Venatrix Roewer: new species, synonymies and generic transfers (Araneae, Lycosidae)
}

\author{
Volker W. Framenau \\ Department of Terrestrial Invertebrates, Western Australian Museum, Locked Bag 49, \\ Welshpool DC, Western Australia 6986, Australia
}

\begin{abstract}
Three species in the wolf spider genus Venatrix Roewer, 1960 are described as new: $V$. amnicola sp. nov. from south-east Australia, $V$. tinfos sp. nov. from Western Australia and $V$. palau sp. nov. from Queensland, the Federated States of Micronesia and Palau. Venatrix kosciuskoensis (McKay, 1974) comb. nov., V. summa (McKay, 1974) comb. nov., and V. ornatula (L. Koch, 1877) $(=V$. forsteri Framenau and Vink, 2001, new synonymy) are transferred from Lycosa to Venatrix, and V. magkasalubonga (Barrion and Litsinger, 1995) comb. nov. (= Pardosa daniloi Barrion and Litsinger, 1995, new synonymy; = Pardosa sacayi Barrion and Litsinger, 1995, new synonymy; = Pardosa hawakana Barrion and Litsinger, 1995, new synonymy) is transferred from Pardosa. Allocosa percauta (Simon, 1909), Lycosa marcentior Simon, 1909 and Lycosa propitia Simon, 1909 are considered junior synonyms of V. pullastra. Venatrix goyderi (Hickman, 1944) and Lycosa howensis McKay, 1979 are considered junior synonyms of Venatrix konei (Berland, 1924) comb. nov. Arctosa konei epiana (Berland, 1938) is elevated to species status, Arctosa epiana (Berland, 1938), stat. nov. The male of $V$. kosciuskoensis and the female of $V$. archookoora are described for the first time. Notes on the type material are provided for $V$. furcillata (L. Koch, 1867) and V. brisbanae (L. Koch, 1878).
\end{abstract}

\section{INTRODUCTION}

The wolf spider genus Venatrix Rower, 1960 is a representative of the wolf spider subfamily Lycosinae, which is currently defined by male pedipalps with a transverse tegular (= median) apophysis carrying a ventrally directed spur and a sinuous channel on its dorsal surface (Dondale 1986). The Lycosinae are the most dominant subfamily of wolf spiders in Australia, in addition to an undescribed subfamily represented by, amongst other unnamed genera, Artoria Thorell, 1877 and Tetralycosa Roewer, 1960 (e.g., Framenau 2002a, 2005; Framenau et al. in press) and the Venoniinae, including Allotrochosina Roewer, 1960, Anomalosa Roewer, 1960, Venonia Thorell, 1894 and Zoica Simon, 1898. Most Australian Lycosinae are currently listed in the genus Lycosa Latreille, 1804, however, recent studies suggest this to be an exclusively Northern Hemisphere genus (Zyuzin and Logunov 2000). It appears that most Australian lycosines, with the exception of Venatrix and Tuberculosa Framenau and Yoo in press, represent a monophyletic group (Murphy et al. in press; Framenau and Yoo in press) and current and forthcoming revisions place the A.ustralian representatives of this subfamily in a variety of endemic genera, such as Dingosa Roewer, 1955a, Hoggicosa Roewer, 1960, Mainosa Framenau (in press), Tasmanicosa Roewer, 1959 and Venator Hogg, 1900.
Venatrix was recently revised in Australia and New Zealand to include 22 species (Framenau and Vink 2001). Since this review, a large amount of material has been examined as part of a comprehensive revision of the Australian wolf spider fauna. This study provides an update of the Venatrix revision with the description of three new species, the transfer of some species formerly included in Lycosa and Pardosa to Venatrix, and the descriptions and illustrations of hitherto unknown sexes. In addition, some new synonymies are established. This study also includes material from outside the former known range of Venatrix, Australia and New Zealand, as original descriptions of some wolf spider species from the Philippines, New Caledonia and Vanuatu suggested the presence of Venatrix in these countries (e.g., Barrion and Litsinger 1995; Berland 1924). This study increases the number of Venatrix to 27 species, of which 12 are treated here (Table 1 ).

\section{METHODS}

Descriptions are based on specimens preserved in $70 \%$ ethanol. Internal female genitalia were cleared for examination by submersion in lactic acid at room temperature for 2-24 hrs. For clarity, the setae have been omitted from the illustrations of epigyna and male pedipalps. The morphological 
nomenclature follows Framenau and Vink (2001). All type material was examined unless otherwise stated. All measurements are in millimetres ( $\mathrm{mm}$ ).

\section{Eyes}

Abbreviations: anterior (AE), anterior median (AME), anterior lateral (ALE), posterior (PE), posterior median (PME), posterior lateral (PLE).

\section{Australian States and Territories}

Abrreviations: Australian Capital Territory (ACT), New South Wales (NSW), Northern Territory (NT), Queensland (Qld), South Australia (SA), Tasmania (Tas), Victoria (Vic), Western Australia (WA).

\section{Collections}

Abbreviations: Australian Museum, Sydney (AM); Australian National Insect Collection, Canberra (ANIC); Natural History Museum, London (BMNH); Bernice Pauahi Bishop Museum, Honolulu, Hawai'i (BPBM); International Rice Research Institute, Entomology Division, Manila (IRRI); Museum National d'Histoire Naturelle, Paris (MHNP); Museum National d'Histoire Naturelle, Troyes (France) (MHNT); Museum Victoria, Melbourne (MV); Museum and Art Gallery of the Northern Territory, Darwin (NTMAG); Queensland Museum, Brisbane (QM); South Australian Museum, Adelaide (SAM); Western Australian Museum, Perth (WAM); Museum für Naturkunde, Zentralinstitut der Humboldt-Universität, Berlin (ZMB); Zoologisches Institut und Zoologisches Museum, Universität Hamburg (ZMH).

\section{SYSTEMATICS}

Family Lycosidae Sundevall, 1833

Subfamily Lycosinae Sundevall, 1833

Venatrix Roewer, 1960

\section{Type species}

Venator fuscus Hogg, 1900. By original designation (Roewer 1960).

Venator fuscus is a junior synonym of Venatrix funesta (C.L. Koch 1847) (Framenau and Vink 2001).

\section{Diagnosis}

Within the Lycosinae, Venatrix can be identified by the presence of a characteristic pattern on the ventral side of the abdomen, consisting of two longitudinal light bands on a dark surface. Sometimes, these bands are reduced to two or more light spots (e.g., in the pictiventris-group) or missing due to an overall light colouration of the venter (e.g., $V$. lapidosa, $V$. fontis, and $V$. arenaris). In some species, this pattern is absent but may be visible in juvenile specimens (e.g., $V$. arenaris) (Framenau and Vink 2001). Males of Venatrix are characterised by a tubercle on the outer edge of the fangs and the presence of claw-like macrosetae on the tip of the cymbium (Framenau and Vink 2001). The female epigyne is usually inverted-T or anchorshaped, however, some species, such as $V$. goyderi Hickman, 1944 and species in the $V$. pictiventrisgroup, deviate from this pattern (Framenau and Vink 2001). In species without the characteristic colouration of the venter it may be difficult or impossible to identify females as Venatrix due to the conservative morphology within the Lycosinae. In this case, generic identification may require the examination of males collected with the females.

\section{Remarks}

Recent morphological investigations showed, that Venatrix hoggi Framenau and Vink, 2001 does not belong to the genus Venatrix due to the presence of unique modified setae on the ventral side of the third coxae in males and a distinct morphology of the male pedipalp with a reduced terminal apophysis (Framenau and Yoo in press). This species is therefore not included in our list of Venatrix (Table 1).

\section{Venatrix amnicola sp. nov. Figures 1A-F, 2, 3}

Venatrix arenaris (Hogg, 1905); Framenau and Vink 2001: 960-962, figures $40 \mathrm{~A}-\mathrm{F}, 41$ (misidentification).

\section{Types}

Holotype male, Australia, Victoria, Avon River near Valencia Creek, 3748'24"S, 14657'14"E, 21 May 1997, V.W. Framenau, riparian gravel bank (WAM T55406).

Paratypes: 2 males, 1 female, Australia, Victoria,

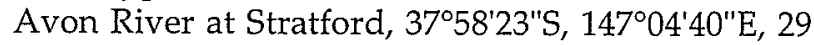
December 2003, V.W. Framenau, M.L. and J. Thomas, riparian gravel bank (WAM T56082).

\section{Etymology}

The specific epithet is an adjective in apposition (Latin, amnicolus - growing beside a river) and refers to the habitat of this species, the riverbanks of the Great Dividing Range.

\section{Other material examined}

Australia: New South Wales: 4 males, 2 females, Honeysuckle Creek, Fish River, 34 $46^{\prime} \mathrm{S}, 149^{\circ} 19^{\prime} \mathrm{E}$, 22 November 1900, J. A. Thorpe (AM KS85164); 1 male, 1 female, Clarence River, Tabulam, 28 $53^{\prime} \mathrm{S}$, $152^{\circ} 34^{\prime}$ E, 21 April 1973, D. Gleeson, on rocks near 
creek (QM W3914). Queensland; 6 males, 6 females Gayndah, 2537'S, $151^{\circ} 37^{\prime}$, R. J. McKav, V. E. Davies, 1 December 1973, dry river sand (QM W5064); 1 female, Goodnight Scrub, 2445 ', $15224 \mathrm{E}$, no collector, at edge of water; eggs laid 30 July 1990 (QM S66813); 1 female, Mingo Crossing, Burnett River, 25 24'S, 151 47'E, 2 December 1973 , R. J. McKay (QM S66816); 3 females, Mitchell River and Desaille Creek junction, Mt Carbine, $1632 \mathrm{~S}$, $145^{\circ} 08^{\prime} \mathrm{E}, 12$ Mav 1973, R. J. McKay, wet river sands (QM W3912); 2 males, 1 female, Pine Creek Dam, Texas, $28^{\circ} 51^{\prime} \mathrm{S}, 151^{\circ} 10^{\prime} \mathrm{E}, 8$ November 1973 , at edge of creek (QM W3913). Victoria: 4 males, 3 females, Avon River at Stratford, 3758'S, $147^{\circ} 04^{\prime} \mathrm{E}, 10$ April 1997, V. W. Framenau, riparian gravel bank (MV K7454); 3 males, 1 female, same location, 26 March 2002, V. W. Framenau, riparian gravelbank (WAM T47300); 9 males, 10 females, same location, V. W. Framenau, riparian gravel bank (AM KS58429, KS58432, KS58436, KS69914-9); 2 males, 1 female, Avon River at Stratford, under highway bridge, $37^{\circ} 58^{\circ} 23^{\prime \prime} \mathrm{S}, 147^{\circ} 40^{\prime \prime} \mathrm{E}, 12$ February 1997, V. W. Framenau, riparian gravel bank (WAM T55400); 1 female, same location, 29 December 2003, V. W. Framenau, M. L. and J. Thomas, riparian gravel bank (WAM T56081); 3 males, 2 females, Avon River at Weirs Crossing, $37^{\circ} 55^{\prime} \mathrm{S}, 147^{\circ} 00^{\prime} \mathrm{E}, \mathrm{V}$. W. Framenau, riparian gravel bank (AM KS58430, KS58433, KS58437, KS69920-5); 15 males, 9 females, Avon River near Valencia Creek, $37^{\circ} 48^{\prime} 24^{\prime \prime} S$, $146^{\circ} 27^{\prime 1} 14^{\prime \prime E}$, V. W. Framenau, riparian gravel bank (AM KS58431, AM KS58434-5, AM KS69926-33); 2 males, same location, 10 April 1997, V. W. Framenau, riparian gravel bank, gravel bank ' 3 ' (WAM T55402); 1 male, 2 females, Cann River at Leslies Track, $37^{2} 28^{\prime}$, $149^{\circ} 11^{\prime} \mathrm{E}, 3$ December 1998 , $\mathrm{V}$. W. Framenau, riparian gravel bank (AM KS58422); 1 male, 1 female, Cann River at Princess Highway bridge, $37^{\circ} 34^{\prime} \mathrm{S}, 1^{\circ} 09^{\circ} \mathrm{E}, 3$ December 1998 , V. W. Framenau, riparian gravel bank (AM KS58420); 1 female, Ensay, 37²2'S, 147 $50^{\prime} \mathrm{E}$, January 1972, A. Fischer (SAM NN10231); 4 males, 2 females, Mitchell River at Wuk Wuk Bridge,

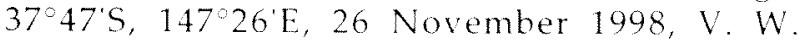
Framenau, riparian gravel bank (AM KS58419, KS69886); 5 males, 1 female, Mitchell River near Angusvale, 37 36'S, 147 21'E, 26 November 1998, V. W. Framenau, riparian gravel bank (AM KS58418); 1 female, Mitta Mitta River, $8 \mathrm{~km}$ NW of Dartmouth Dam, 36 34'S, 147'28'E, 4 November 1976, A. A. Calder (MV K7448); 3 males, 1 female, Ovens River near Wangaratta, 3623'S, $14622 \mathrm{E}, 6$ December 1998 , V. W. Framenau, riparian gravel bank (AM KS58424); 3 males, 2 females, Ovens River near Wangaratta, Ovens Billabong, 3623'S, :4622'E, 6 December 1998, V. W. Framenau, riparian gravel bank (AM KS58432); 1 female with eggsac, Snowy and Broadbent Rivers junction, $37^{\circ} 20^{\prime} \mathrm{S}, 14821^{\prime} \mathrm{E}$, early December 1947, C. W. Brazenoor (MV K7439).

\section{Description}

Male (based on holotype, WAM T55406). Carapace: Brown, with irregular but distinct and wide light brown median band in the anterior two thirds of carapace, which is constricted at about half its length; carapace margins black; light brown submarginal bands represented by three irregular spots; covered with mainly black and a few white setae; white setae in median and submarginal bands; brown bristles around eyes, in particular between PME. Sternum: Dark brown, margins yellow-brown; narrow yellow-brown median band in anterior half; black-brown setae increasing in length and density towards margins. Labium: Brown, base very dark; front end truncate and white. Chelicerae: Reddish-brown, white setae and fewer brown bristles mainly in basal half; three retromarginal teeth of nearly equal size; three promarginal teeth, with the middle one largest. Pedipalp (Figures 1A-C): Terminal apophysis triangular with rounded tip that is bent ventrally, embolus sickle-shaped (Figure 1C). Abdomen: Light vellow-brown with dark and irregular olive-grey, mottled pattern; indistinct orange lanceolate heart mark; colour of setae corresponding to pigmentation, heart mark with very dense whitish setae; few brown macrosetae; venter yellow-brown, indistinct olive-grey pattern medially; covered with white setae and fewer brown macrosetae; spinnerets brown with darker base. Legs: Leg formula IV > I > II > III; brown, with the apical segments darker; very distinct dark annulations; spination of leg I: femur: 3 dorsal, 2 prolateral, 3 retrolateral; patella: 1 prolateral; tibia: 3 ventral pairs, 2 prolateral, 2 retrolateral; metatarsus: 3 ventral pairs, 2 prolateral, 1 retrolateral, 1 apicoventral, 1 apicoprolateral, 1 apicoretrolateral.

Female (based on paratype, WAM 56082). Carapace: As male, less white setae. Sternum: As male, but darker and with additional few white setae. Labium: As male. Chelicerae: Very dark reddish-brown; setae and dentition as male. Epigyne (Figures 1D, E): Ventral view: medium septum inverted T-shaped (Figure 1D); dorsal view: spermathecae elongate oval; copulatory ducts Sshaped and connect posteriorly to spermathecae (Figure 1E). Abdomen: Mottled yellow-brown and dark olive-grey; some lighter patches in two rows medially; lanceolate heart mark very indistinct, discernable only by dense silver-grey setae; covered with silver-grey and brown setae and fewer brown macrosetae; venter and spinnerets as male. Legs: Leg formula IV $>$ I $>$ II $>$ III; colouration as male; weak scopulous setae on tarsi and metatarsi of leg I and tarsi and apical half of metatarsi of leg II: femur: 3 dorsal, 2 retrolateral (3 on right leg), 1 apicoprolateral; tibia: 3 ventral pairs, 2 prolateral; metatarsus: 3 ventral pairs, 1 prolateral, 1 apicoventral. 

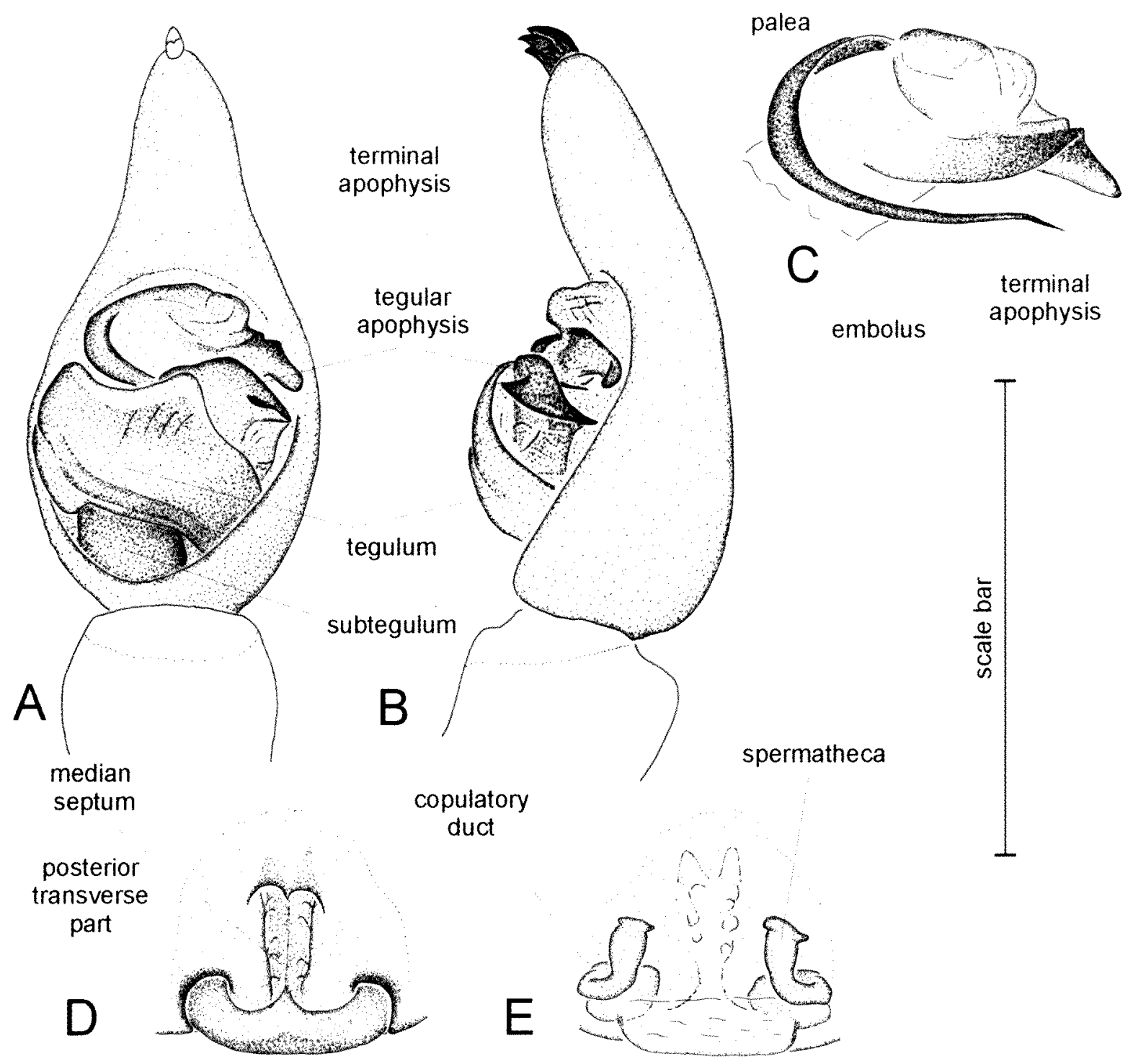

Figure 1 Venatrix amnicola sp. nov., holotype male (WAM T55406, from the Avon River near Valencia Creek, Victoria): A, left pedipalp, ventral view; B, left pedipalp, retrolateral view; C, left pedipalp, apical part of bulbus. Female (WAM T56082, from the Avon River at Stratford, Victoria): D, epigyne, ventral view; E, epigyne, dorsal view. Scale bar: $A, B=1.01 \mathrm{~mm} ; C=0.57 \mathrm{~mm} ; D, E=1.32 \mathrm{~mm}$.

Measurements. Male holotype, WAM T55406 (female paratype, WAM T56082): TL 7.24 (8.46), CL 3.95 (4.70), CW 2.82 (3.48). Eyes: AME $0.17(0.19)$, ALE 0.11 (0.14), PME 0.28 (0.35), PLE $0.26(0.28)$. Row of eyes: AE $0.67(0.91)$, PME 0.75 (0.91), PLE 1.03 (1.22). Sternum (length/width) 1.97/1.41 (2.16/ 1.79). Labium (length/width) $0.45 / 0.55(0.68 / 0.64)$. AL 3.38 (3.76), AW 2.26 (3.01). Legs: Lengths of segments (femur + patella/tibia + metatarsus + tarsus $=$ total length): Pedipalp $1.50+1.41+-+1.13=$ 4.04 , I $2.91+3.67+2.44+1.69=10.71$, II $2.91+3.57+2.40+1.60=10.48$, III $2.73+3.10+2.54+1.41=$ 9.78, IV $3.38+4.04+3.48+1.88=12.78$ (Pedipalp $1.69+1.88+-+1.13=4.70$, I $3.48+4.04+2.63+1.88=$ 12.03 , II $3.38+3.76+2.54+1.79=11.47$, III $3.10+3.38+3.01+1.69=11.18$, IV $3.95+4.70+4.23+2.07$ $=14.95$ ).
Variation. Males (females)(range, mean \pm s.d.): TL 7.20 - 8.40, 7.76 \pm 0.52 ; CL $3.75-5.10,4.42 \pm 0.50$; CW $2.82-3.75,3.25 \pm 0.39 ; \mathrm{n}=7$ (TL $8.46-11.55$, $10.12 \pm 1.56$; CL $4.70-5.10,4.97 \pm 0.23$; CW $3.48-$ $3.86,3.69 \pm 0.18 ; \mathrm{n}=3$ ). Live spiders do have a mottled, cryptic colouration, which provides camouflage in their natural environment, sandy and gravel banks of rivers (Figure 2).

\section{Remarks}

This species was previously regarded as a morphological variety of $V$. arenaris (Framenau and Vink 2001). The recent examination of additional material in combination with molecular data, however, indicated that $V$. amnicola represents a distinct species. Specimens of $V$. amnicola from the Avon River (Victoria) showed 33\% fixed differences 


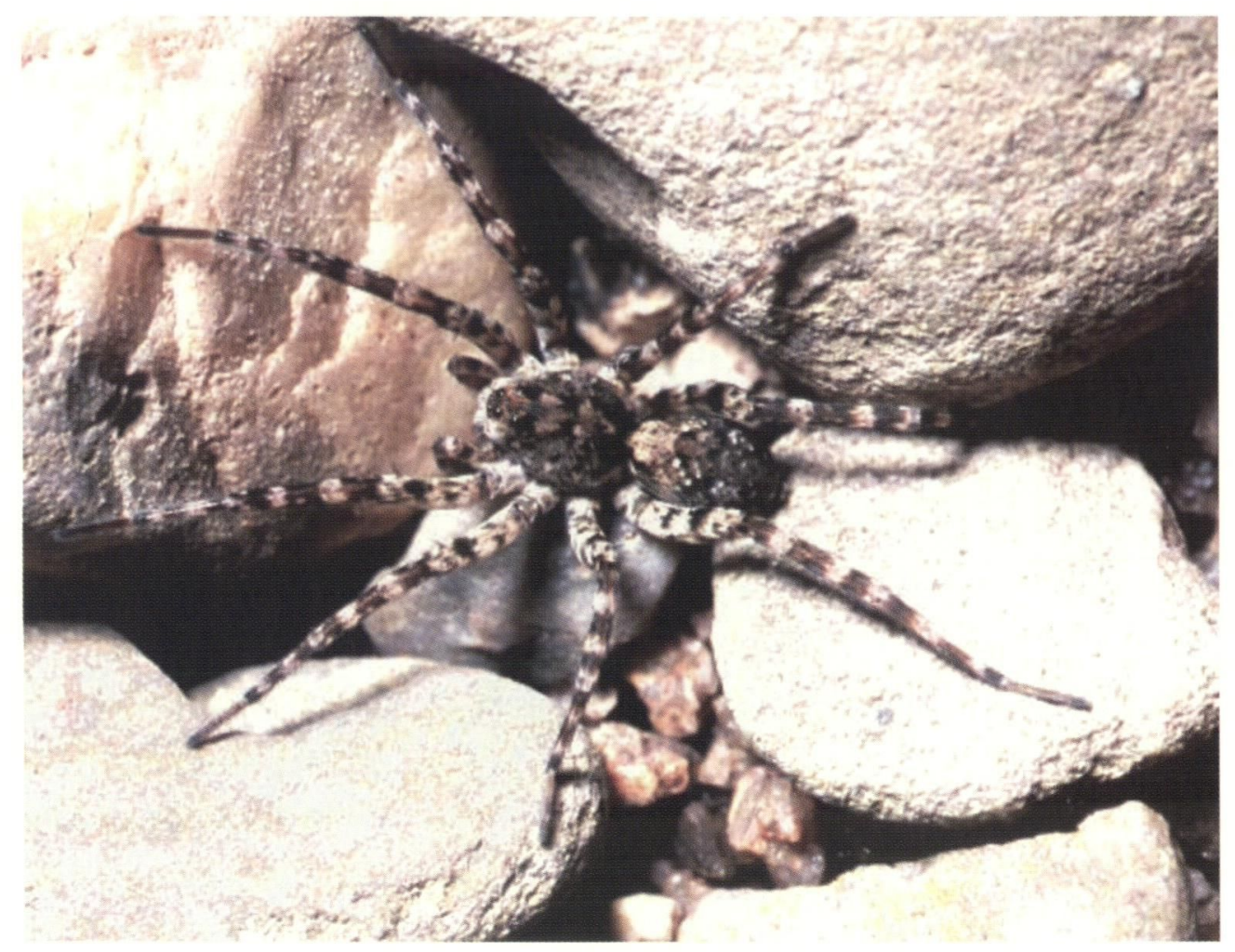

Figure 2 Venatrix amnicola, male from the Avon River at Valencia Creek, Victoria. Body length ca. $8 \mathrm{~mm}$.

in allele frequencies compared with $V$. arenaris specimens from artesian springs in South Australia (Gotch 2003).

In the key to Venatrix (Framenau and Vink 2001), males and females of $V$. amnicola will key out to $V$. arenaris (Hogg, 1905). The diagnosis above will serve to differentiate both species.

\section{Life history and habitat preferences}

Venatrix amnicola has only been found on the sandy and gravel riverbanks of the Great Dividing Range and was subject to a major investigation of this habitat, then misidentified as $V$. arenaris (Framenau 1998, 2002b; Framenau et al. 2002). It inhabits the lowland floodplains of alpine rivers

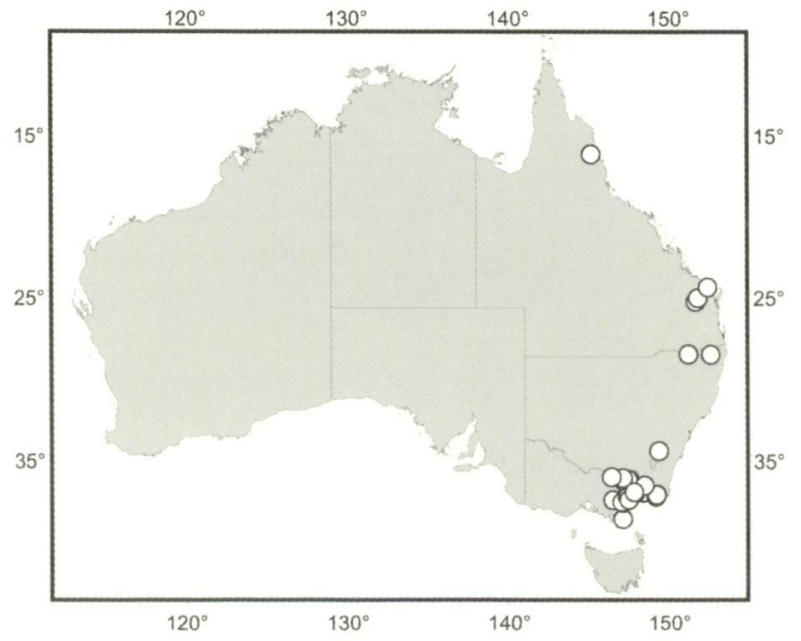

Figure 3 Records of Venatrix amnicola sp. nov. where a number of ecological factors such as altitude, degree of shade, gravel size and gravel bank size appear to determine the arthropod community structure (Framenau et al. 2002). In Victoria, $V$. amnicola completes its life cycle in one year; juveniles hatch in spring, mature by autumn and reproduce the following spring (Framenau 1998).

\section{Distribution}

New South Wales, Queensland, and Victoria (Figure 3).

Venatrix archookoora Framenau and Vink, 2001 Figures $4 \mathrm{~A}-\mathrm{B}, 5$

Venatrix archookoora Framenau and Vink, 2001: 940-942, figures 14a-c, 15.

\section{Types}

Holotype male of Venatrix archookoora, Australia, Queensland, Archookoora State Forest, via Kumbia, $26^{\circ} 43^{\prime}$ S, $151^{\circ} 47$ E, 17 October 1976, G.B and S.R. Monteith (QM S45307). Examined.

Paratype male, Australia, Queensland, Amiens, near Stanthorpe, $28^{\circ} 35^{\prime} \mathrm{S}, 151^{\circ} 49^{\prime} \mathrm{E}$ (QM S45294). Examined.

\section{Diagnosis}

Males of $V$. archookoora are similar to those of $V$. australiensis, $V$. roo and $V$. mckayi, but differ in the shape of the tegular apophysis which is uniquely 
triangular in ventral view with a small pointed protrusion on its apical edge (Framenau and Vink 2001). The epigyne of female $V$. archookoora resembles that of $V$. arenaris, $V$. amnicola and $V$. palau, and the species will key out to $V$. arenaris in the key of the genus in Framenau and Vink (2001). However, $V$. archookoora differs distinctly in its dark reddish-brown carapace and overall colouration from the above species with their light brown mottled pattern.

\section{Other material examined}

Australia: Queensland: 2 males, Binjour Plateau, Swains Road, $25^{\circ} 32^{\prime} \mathrm{S}, 151^{\circ} 30^{\prime} \mathrm{E}, 23$ September -21 December 1997, G. Monteith, D. Cook, 340m, vine scrub (QM S44305); 2 males, same location, 20 December 1997 - 26 April 1998, G. Monteith, vine scrub (QM S46395); 1 female, Boat Mountain summit Environmental Park., 26 $09^{\prime} \mathrm{S}, 151^{\circ} 59^{\prime} \mathrm{E}, 9$ September - 15 December 1994, G. Monteith, vine scrub (QM S66674); 2 males, Brigooda, Koy Property, $26^{\circ} 16^{\prime} \mathrm{S}, 151^{\circ} 25^{\prime} \mathrm{E}, 15$ December $1994-26$ January 1995, G. B. Monteith, vine scrub, bottom site (QM S57043); 1 male, 1 female, same location, 26 January - 20 April 1995, G. B. Monteith, vine scrub, top site (QM S31603); 1 male, Coalston Lakes, $26^{\circ} 11^{\prime} \mathrm{S}, 152^{\circ} 04^{\prime} \mathrm{E}, 26 \mathrm{March}-5$ September 1997, G. and S. Monteith, vine scrub, GM72A/3 (QM S66674); 1 female, same location, 29 August - 13 December 1976, G. and S. Monteith, GM72A/1 (QM S66670); 4 males, Cobbs Hill, 26ㅇ' ${ }^{\circ} \mathrm{S}, 1^{\circ} 1^{\circ} 54^{\prime} \mathrm{E}, 19$ December 1992 - March 1993, S. Hamlet, site 1 (QM S27402); 2 males, same location, S. Hamlet, site 2 (QM S27413); 4 males, 1 female, Crater National Park, Atherton Tableland, $17^{\circ} 26^{\prime} \mathrm{S}, 1^{\circ} 5^{\circ} 29^{\prime} \mathrm{E}, 28$ December 1990, G. B. Monteith, 950m (QM S41641); 2 males, 2 females, Expedition Range National Park, 'Amphitheatre' scrub, 2513'S, 148 $59^{\prime} \mathrm{E}, 25$ September - 17 December 1997, G. Monteith, D. Cook, vine forest (QM S66669); 2 males, Gurgeena Plateau, $25^{\circ} 27^{\prime} \mathrm{S}, 151^{\circ} 23^{\prime} \mathrm{E}, 27$ January - 2 June 1999 , G. Monteith, G. Thompson, 360m, open forest (QM S50718); 2 males, same location, 20 August - 9 October 1998, G. B. Monteith, 360m, rainforest (QM S59225); 1 male, same location, 27 January - 2 June 1999, G. Monteith, G. Thompson, open forest (QM S66673); 1 male, Hurdle Gully, $13 \mathrm{~km}$ WSW Monto, $24^{\circ} 51^{\prime} \mathrm{S}, 151^{\circ} 00^{\prime} \mathrm{E}, 23$ September - 20 December 1997, G. Monteith, D. Cook, 350m, semi-evergreen vine thicket (QM S44397); 1 male, 1 female, Hurdle Gully, $10.8 \mathrm{~km}$ WSW Monto, $24^{\circ} 54^{\prime} \mathrm{S}, 151^{\circ} 01^{\prime} \mathrm{E}, 23$ September - 20 December 1997, intercept trap, G Monteith, D. Cook, vine scrub (QM S32531); 1 male, Keysland, $26^{\circ} 12^{\prime} \mathrm{S}, 151^{\circ} 44^{\prime} \mathrm{E}, 29$ September $1994-15$ December 1994, G. B. Monteith, open forest (QM S37742); 5 males, Nangur State Forest, $26^{\circ} 08^{\prime} \mathrm{S}$, $151^{\circ} 59^{\prime} \mathrm{E}, 29$ July 1995 - 23 October 1995, G. B. Monteith, 320m, rainforest, second site (QM S41636, S41649); 4 males, 2 females, same location, 24
October- 24 November 1995 , G. B. Monteith, 320m, rainforest, first site (QM S51084); 1 male, 1 female, same location, 24 October - 24 November 1995, G. B. Monteith, $320 \mathrm{~m}$, rainforest, second site (QM S43799); 12 males, 2 females, 1 female with eggsac, same location, 24 November 1995 - 3 February 1996, G. B. Monteith, rainforest, first site (QM S37653); 1 male, 3 females, Nipping Gully, 254' S, 151 $26^{\prime} \mathrm{E}, 9$ October - 18 December 1998, G. Monteith, C. Gough, 200m, rainforest, site 2 (QM S49534); 2 males, 1 female, same location, 25 January - 2 February 1999, G. Monteith, G. Thompson, 240m, rainforest (QM S52029); 1 male, same location, 26 January - 2 June 1999, G. Monteith, G. Thompson, $300 \mathrm{~m}$, rainforest, site 2 (QM S51948); 2 males, same location, 18 December 1998 - 25 January 1999, G.Monteith, C. Gough, rainforest, site 5 (QM S34857); 2 females, "Pearlinga", via Mundubbera,

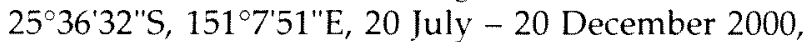
D. Cook, G. Monteith, $160 \mathrm{~m}$, semi-evergreen vine thicket (QM S57727); 2 males, same location, 20 December 2000 - 23 March 2001, D. Cook, G. Monteith, vine scrub (QM S66672); 1 male, The Bluff, Keysland, $26^{\circ} 15^{\prime} \mathrm{S}, 151^{\circ} 43^{\prime} \mathrm{E}, 29$ July -23 October 1995, G. B. Monteith, 530m, vine scrub (QM S51077); 3 males, same location, 24 October - 24 November 1995, G. B. Monteith, $530 \mathrm{~m}$, vine scrub (QM S51079); 3 males, same location, 24 November 1995 - 3 February 1996, G. B. Monteith, vine scrub (QM S37662); 1 female, Wetherton, $3 \mathrm{~km} \mathrm{SW}$, $25^{\circ} 34$ 'S, $151^{\circ} 42^{\prime} \mathrm{E}, 10$ October - 19 December 1998, G. Monteith, C. Gough, vine scrub (QM S66671); 4 males, Wonga Hills, 26 $4^{\circ} 07^{\prime \prime} \mathrm{S}, 150^{\circ} 49^{\prime} 29^{\prime \prime} \mathrm{E}, 10$ October - 11 December 2001, G. Monteith, D. Cook, $500 \mathrm{~m}$, softwood scrub, site 2 (QM S57108); 8 males, Woodmillar (East), 25⒋'S, 151 ${ }^{\circ} 36^{\prime} \mathrm{E}, 25$ January - 2 June 1999, G. Monteith, G. Thompson, $350 \mathrm{~m}$, vine scrub (QM S51912); 7 males, same location, 21 August - 10 October 1998, G. Monteith, vine scrub (QM S66668).

\section{Description}

Male. See Framenau and Vink (2001). The size variation of a larger number of males is given below.

Female (based on paratype, WAM T56082). Carapace: Reddish-brown, with dark radial pattern; orange-brown median band, widest posteriorly of PLE and narrowing continuously; two small brown spots in median band between PLE and fovea; very indistinct lighter submarginal band; head flanks distinctly darker; white and black setae, but only white setae in median band and eye region and mainly black setae on dark head flanks; a band of white setae from below the PLE to carapace margin; brown-black bristles around eye region some in median band anterior of fovea; six long bristles below $\mathrm{AE}$, one long bristle between AME. Sternum: Reddish-brown with indistinct lighter, narrow 


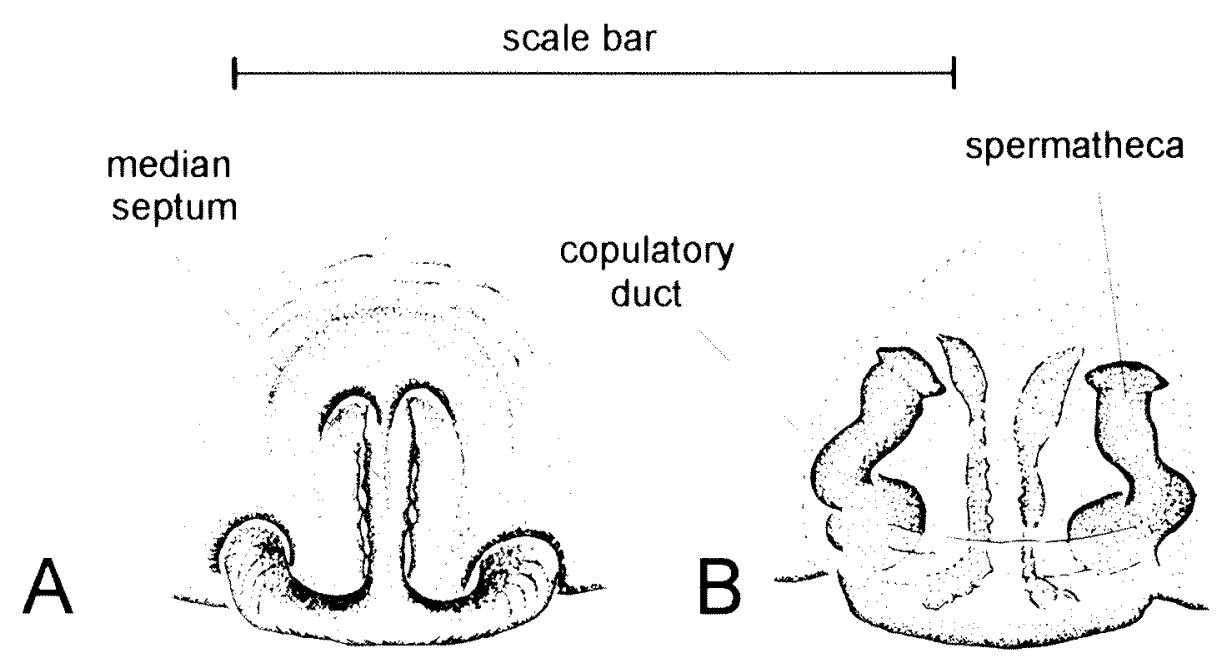

Figure 4 Venatrix archookoora Framenau and Vink, 2001, female (QM 32531, from Hurdle Gully, Queensland): $A$, epigyne of, ventral view; $B$, epigyne, dorsal view. Scale bar: $A, B=1.30 \mathrm{~mm}$.

median band in anterior half; covered with black setae and bristles which are longer towards margin. Labium: Brown-black, front end truncate and white. Chelicerae: Black-brown, light brown setae in basal third, black setae apically, fewer longer brown bristles mainly medially. Epigyne (Figures 4A, B): Ventral view: medium septum inverted $\mathrm{T}$-shaped, longitudinal part with slightly serrated edges (Figure 4A); dorsal view: spermathecae and copulatory ducts of similar width, spermathecae with apical hood-like structure (Figure 4B). Abdomen: Olive-grey, medially lighter with two pairs of darker spots in posterior half; brown and white setae, fewer brown macrosetae; venter uniformly very dark olive-grey, brown setae; spinnerets dark brown. Legs: Leg formula IV > I > II $>$ III; orange brown, femora and tibiae with indistinct light annulations through rings of white setae; spination of leg $\mathrm{I}$ : femur: 3 dorsal, 3 retrolateral, 2 apicoprolateral; patella: 1 prolateral;

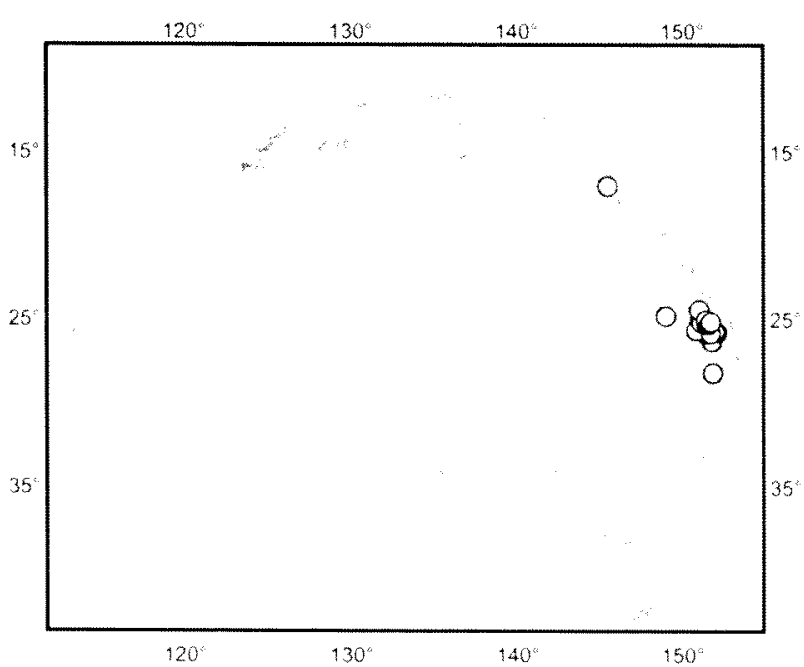

Figure 5 Records of Venatrix archookoora Framenau and Vink, 2001 tibia: 3 ventral pairs, 2 prolateral, 2 retrolateral; metatarsus: 3 ventral pairs, 2 prolateral, 1 retrolateral, 1 apicoventral, 1 apicoprolateral, 1 apicoretrolateral.

Measurements. Female, QM S32531: TL 12.41, CL 6.58, CW 4.79. Eyes: AME 0.25, ALE 0.18, PME 0.53, PLE 0.45. Row of eyes: AE 1.22, PME 1.22, PLE 1.63. Sternum (length/width) 2.44/2.26. Labium (length/ width) $0.87 / 0.99$. AL 4.89, AW 4.14. Legs: Lengths of segments (femur + patella/tibia + metatarsus + tarsus $=$ total length): Pedipalp $2.44+2.26+-+1.88=$ 6.58 , I $4.70+5.64+3.57+2.16=16.07$, II $4.42+5.08+3.29+2.07=14.86$, III $4.14+4.61+3.38+1.79=$ 13.92, IV $5.45+6.20+5.83+2.26=19.74$

Variation. Males (females)(range, mean \pm s.d.): TL 7.95 - 10.50, 9.27 \pm 0.65 ; CL $4.50-6.00,5.15 \pm 0.40$; CW $3.15-4.50,3.76 \pm 0.34 ; \mathrm{n}=21$ (TL 10.50-15.00, $12.39 \pm 1.36 ; \mathrm{CL} 4.95-7.80,6.33 \pm 0.86 ; \mathrm{CW} 3.45-$ $6.00,4.61 \pm 0.78 ; \mathrm{n}=12$ ).

\section{Remarks}

When Framenau and Vink (2001) described $V$. archookoora, the species was only known from two males. The hitherto unknown female is here described for the first time.

\section{Life history and habitat preferences}

The activity of males judged by pitfall trap periods, appears to be highest from October to January (spring and early summer) and females appear in lower numbers and slightly later. The species appears to inhabit a variety of shady habitats, such as open forest, vine forest and scrub, and rainforest. It was found at elevations between 150 and $900 \mathrm{~m}$.

\section{Distribution \\ Queensland (Figure 5).}


Venatrix brisbanae (L. Koch, 1878)

Lycosa brisbanae L. Koch, 1878: 976-978, plate 85, figures 4, 4a, 4b; Rainbow 1911: 266; McKay 1985: 75 .

Pirata brisbanae (L. Koch); Roewer 1955b: 286; McKay 1973: 381.

Lycosa brisbanensis L. Koch; Bonnet 1957: 2636.

Venatrix brisbanae (L. Koch); Framenau and Vink 2001: 953-954, figures 30A-F, 31.

\section{Type}

Holotype female of Lycosa brisbanae, Australia, Queensland, Brisbane, $27^{\circ} 28^{\prime} \mathrm{S}, 1^{\circ} 3^{\circ} 01^{\prime} \mathrm{E}$ (MHNT AR0820). Examined.

\section{Remarks}

The identification of $V$. brisbanae in Framenau and Vink (2001) was solely based on the original description as the whereabouts of the type material was not known. The recent discovery and examination of the holotype in the Museum National d'Histoire Naturelle, Troyes (France) confirmed the identity of this species as diagnosed and revised in Framenau and Vink (2001).

\section{Venatrix furcillata (L. Koch, 1867)}

Lycosa furcillata L. Koch, 1867: 201-202; L. Koch 1877: 903-906, plate 78, figures $1 \mathrm{a}-\mathrm{b}, 2 \mathrm{a}-\mathrm{b}$; Rainbow 1911: 268; Rack 1961: 37; McKay 1973: 379; McKay 1974a: 15-18, figure 3c, d, k-m; McKay 1985: 77; Platnick 1993: 487.

Allocosa furcillata (L. Koch); Roewer 1955b: 206.

Venatrix furcillata (L. Koch); Framenau and Vink 2001: 957-959, figures 36A-D, 37.

\section{Type}

Holotype immature (?) of Lycosa furcillata, Australia, Queensland, Brisbane, $27^{\circ} 28^{\prime} \mathrm{S}, 153^{\circ} 01^{\prime} \mathrm{E}$, Queensland. Whereabouts unknown. Not examined.

\section{Remarks}

Venatrix furcillata was originally described from a single specimen (holotype) collected by Amalie Dieterich in Brisbane and deposited in the collection of the Museum Godeffroy (L. Koch 1867). This specimen may have been a juvenile since the description does not mention male or female genitalia as in other species of the same publication. Subsequently, L. Koch (1877) redescribed and illustrated males and females of $V$. furcillata, listing numerous specimens from Bowen, Brisbane, Port Mackay, Gayndah (all Queensland) and Sydney (New South Wales) deposited in the Museum Godeffroy, but also specimens in the Museum National d'Histoire Naturelle, Troyes (France) from Brisbane and some specimens from Sydney in the Bradley Collection. More recently, a catalogue of the material in the ZMH mistakenly listed a 'syntype' of $V$. furcillata from Sydney (Rack 1961) most likely referring to the series of species on which L. Koch's (1877) redescription (but not original description) was based. McKay (1974a) designated a lectotype from what he also presumed to be syntypes, all from the Godeffroy Museum, collected in Sydney and deposited in the Natural History Museum, London. Framenau and Vink (2001) expanded this list with additional paralectotypes. All references to syntypes and the designation of a lectotype series of $V$. furcillata must be considered invalid, since the original description of this species was based on a single specimen, i.e., a holotype.

I have examined all major collections which today house material from the Museum Godeffroy (BMNH, ZMB, ZMH) but could not find a specimen that agrees with the description of the holotype of $V$. furcillata and was collected or labelled 'Brisbane'. Therefore, I consider the holotype of $V$. furcillata lost. However, due to L. Koch's (1877) accurate redescription, there is no doubt about the identity of this species as revised in McKay (1974a) and Framenau and Vink (2001).

Venatrix konei (Berland, 1924), comb. nov.

Lycosa albosparsa sensu Hogg, 1896: 314, 351; not L. Koch 1876: 886, plate 76, figure 4 (misidentification, L. albosparsa considered nomen dubium in Framenau and Vink 2001).

Lycosa konei Berland, 1924: 245-246, figures 197199; Bonnet 1957: 2648

Lycosa goyderi Hickman, 1944: 33-34, plate 2, figure 20; McKay 1985: 78. New synonymy.

Mustelicosa goyderi (Hickman, 1944); Roewer 1955b: 280.

Arctosa konei (Berland, 1924); Roewer 1955b: 230.

Piratosa goyderi (Hickman, 1944); Roewer 1960: 915; Platnick 1993: 506.

Arctosa goyderi (Hickman, 1944); McKay 1973: 380.

Lycosa howensis McKay, 1979a: 237-238: figures 1a-e; McKay 1985: 78; Platnick 1989: 371. New synonymy.

Venatrix goyderi (Hickman, 1944); Framenau and Vink 2001: 963-965, figures 44A-E, 45; Vink 2002: 39, figures 5, 33, 40, 67, 94, map 27; Framenau et al. in press: figures 15-17. 


\section{Types}

Lectotype female (designated here) of Lycosa konei, New Caledonia, labelled 'Vallee 'Tiaouka' (= ?Tiwaka) [Berland (1924) states 'Station au bord du fleuve Konél, 21 $05^{\prime} \mathrm{S}, 164^{\circ} 48^{\prime} \mathrm{E}$ (coordinates for Koné River), 23 August 1911, Roux and Sarasin (MHNP). Examined.

Paralectotype female (penultimate) of Lycosa konei, data as lectotype (MHNP). Examined.

Paralectotype female of Lycosa konei, New Caledonia, Bopope, 2055'S, 165.04'E, August 1911 (listed as 'cotype' by Berland, 1924) (MHNP?, not received with other type material). Not examined.

Holotype female of Lycosa goyderi, Australia, South Australia, Goyders Lagoon Bore, $27^{\circ} 01^{\prime} \mathrm{S}$, $138^{\circ} 54^{\prime} \mathrm{E}, 1939$, Simpson Desert Expedition, coll. 647 (AM KS49705). Examined.

Holotype female of Lycosa howensis, Australia, New South Wales, Lord Howe Island, Lagoon Road, North of Blinky Beach Road turnoff, $31^{\circ} 32^{\prime} 30^{\prime \prime} \mathrm{S}, 1^{\circ} 9^{\circ} 04^{\prime} 30^{\prime \prime} \mathrm{E}, 3$ February 1971, M. R. Gray, Station 25 (AM KS60). Examined.

Paratypes of Lycosa howensis, 3 males, 4 juv., data as holotype (AM KS 61-63). Examined.

\section{Diagnosis}

Males of V. konei can be separated from all other species in the genus by the unique shape of the terminal apophysis, that forms a roof over the resting embolus. The hoods of the female epigyne touch centrally and the median septum is only weakly scerotised (see diagnosis of $V$.goyderi in Framenau and Vink 2001).

\section{Remarks}

Venatrix goyderi had recently been recorded from New Caledonia (C.) Vink, personal communication, Framenau et al. in press) and an assessment of original descriptions of New Caledonian spiders (e.g., Berland 1924) suggested Lycosa konei to have very close affinities to $V$. goyderi. Subsequent examination of the type material of $L$. konei showed no distinct differences in genitalic and somatic characters of both species. Therefore, $V$. goyderi and its synonym Lycosa howensis (Framenau and Vink 2001) are here considered junior synonyms of $L$. konei and the species is transferred to Venatrix. The syntype series consists of 'types', a female and a penultimate female, and an adult female 'cotype' (Berland 1924). A lectotype is designated here to stabilise the taxonomic concept of $V$. konei.

Berland (1938) subsequently described a new subspecies of $V$. konei, Lycosa konei var. epiana Berland, 1938, currently listed in Arctosa (Platnick 2005). The types of Lycosa konei var. epiana are not present in the MHNP (C. Rollard personal communication) where, as part of the collection of $\mathrm{Mr}$ and Mrs Aubert de la Ruë, they should be housed (Berland 1938). However, the original description of A. konei var. epiana clearly shows that this species is not conspecific with $V$. konei. The male pedipalp, illustrated in Berland (1938), has a sickle-shaped terminal apophysis and is not similar to the roof-shaped structure that is very characteristic for $V$. konei. In addition, the female epigyne of $A$. konei var. epiana is inverted Tshaped without the distinct separate anterior hoods of $V$. konei. Consequently, the subspecies $A$. konei var. epiana is removed from its synonymy with $V$. konei and elevated to species status, Arctosa epiana (Berland 1938), stat. nov. It is retained in its current genus Arctosa, pending an examination of the type material.

\section{Venatrix kosciuskoensis (McKay, 1974) comb. nov.}

Figures $6 \mathrm{~A}-\mathrm{C}, 7$

Lycosa kosciuskoensis McKay, 1974b: 31-34, figures 1d-f, j-l; Brignoli 1983: 450; McKay 1985: 79.

\section{Types}

Holotype female of Lycosa kosciuskoensis, Australia, New South Wales, Mt Kościuszko near Lake Albina, $36^{\circ} 27^{\prime} \mathrm{S}, 148^{\circ} 16^{\prime} \mathrm{E}$, 6 January 1929, A. Musgrave (AM KS628). Examined.

Paratypes of Lycosa kosciuskoensis (all from Australia, New South Wales): 1 female, data as holotype (AM KS629); 1 female, 2 juveniles, Mt Kościuszko, 3627'S, $148^{\circ} 16^{\prime} \mathrm{E}, 7$ January 1929, A. Musgrave, H.O. Fletcher, 7000ft (AM KS625, KS630); 1 female, Mt Kościuszko, 36 27'S, $148^{\circ} 16^{\prime} \mathrm{E}$, A. Musgrave, H.O. Fletcher, 7000ft (AM KS632); 3 females, Mt Kościuszko, 36 27'S, $148^{\circ} 16^{\prime} \mathrm{E}, 7$ January 1929, A. Musgrave, H.O. Fletcher (KS627); 3 females, 2 juveniles, Mt Kościuszko, summit, $36^{\circ} 27^{\prime} \mathrm{S}, 148^{\circ} 16^{\prime} \mathrm{E}, 11$ January 1929, A. Musgrave, H.O. Fletcher, 7328ft (AM KS626); 1 juvenile, Mt Kościuszko near Lake Coatapatamba, 36.27's, $148^{\circ} 16^{\prime} \mathrm{E}, 7$ January 1929, A. Musgrave, H.O. Fletcher (AM KS631). All examined.

\section{Diagnosis}

Venatrix kosciuskoensis can be distinguished from all other species of Venatrix by its unique ventral pattern displaying a pair of white spots in the posterior half on a dark surface. Due to this unique pattern the key to the species of Venatrix (Framenau and Vink 2001) fails in the first couplet to identify this species

\section{Other material examined}

New South Wales: 1 female, Mt Kosciuszko National Park, $3 \mathrm{~km}$ NE of Mt Twynham, 28 December 1981, B.F. Roberts, walking on ground, daytime (MV K7436): 1 female, Rock Creek, Mt Kościuszko, 3627S, 14816' F, 25 November 1952 , 
A. Musgrave, $1833 \mathrm{~m}$, among snow grass against rocks (AM KS85153); 1 female, Spencers Creek, Mt Kościuszko, 36 $21^{\prime}$ S, $148^{\circ} 32^{\prime}$ E, 22 November 1952, A. Musgrave, 5-6000ft (AM KS70011); 1 female, Wilsons Valley, Mt Kościuszko, Boonbar, $5000 \mathrm{ft}$ (AM KS85152); 1 female, Mt Coruthers, Maria Range, $100 \mathrm{~m}$ E of junction Blue Lake Track with Lakes Track on Maria Range, 36 23'S, 148 $19^{\prime} \mathrm{E}, 26$ February 1934, fen vegetation (ANIC). Victoria: 1 male, Falls Creek, 39 $53^{\prime} \mathrm{S}, 147^{\circ} 16^{\prime} \mathrm{E}$, 13 December 1992, J. Dawson, alpine grassland (QM S21161); 1 female, Mt Buller Ski Resort, 3708'S, 146 $27^{\circ} \mathrm{E}, 5$ May 1975, V. Salitrini (QM S66445); 1 female, Suggan Buggan - Thredbo track, 36 $57^{\prime} \mathrm{S}, 148^{\circ} 19^{\prime} \mathrm{E}$, 29 December 1976, V. Salitrini (QM S66444).

\section{Description}

Male (based on QM S21161). Carapace: Dark reddish-brown with distinct and wide orangebrown median and submarginal bands; submarginal bands reach to frontal margin of carapace; carapace covered with black setae, except in median and submarginal bands which have white setae; dark brown bristles mainly around PME, one long brown bristle between AME, six long brown bristles below AE. Sternum: Black; black setae increasing in length towards margins. Labium: Black; front end truncate and white. Chelicerae: Very dark reddish-brown, patch of dense orange setae in basal half; three retromarginal teeth, with the middle one largest; three

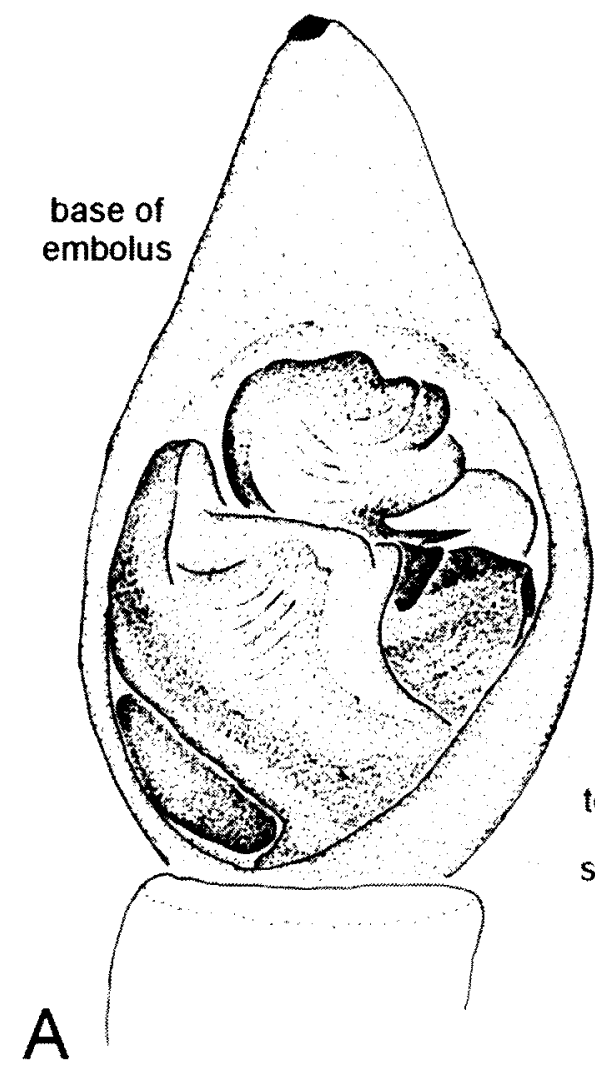

median septum

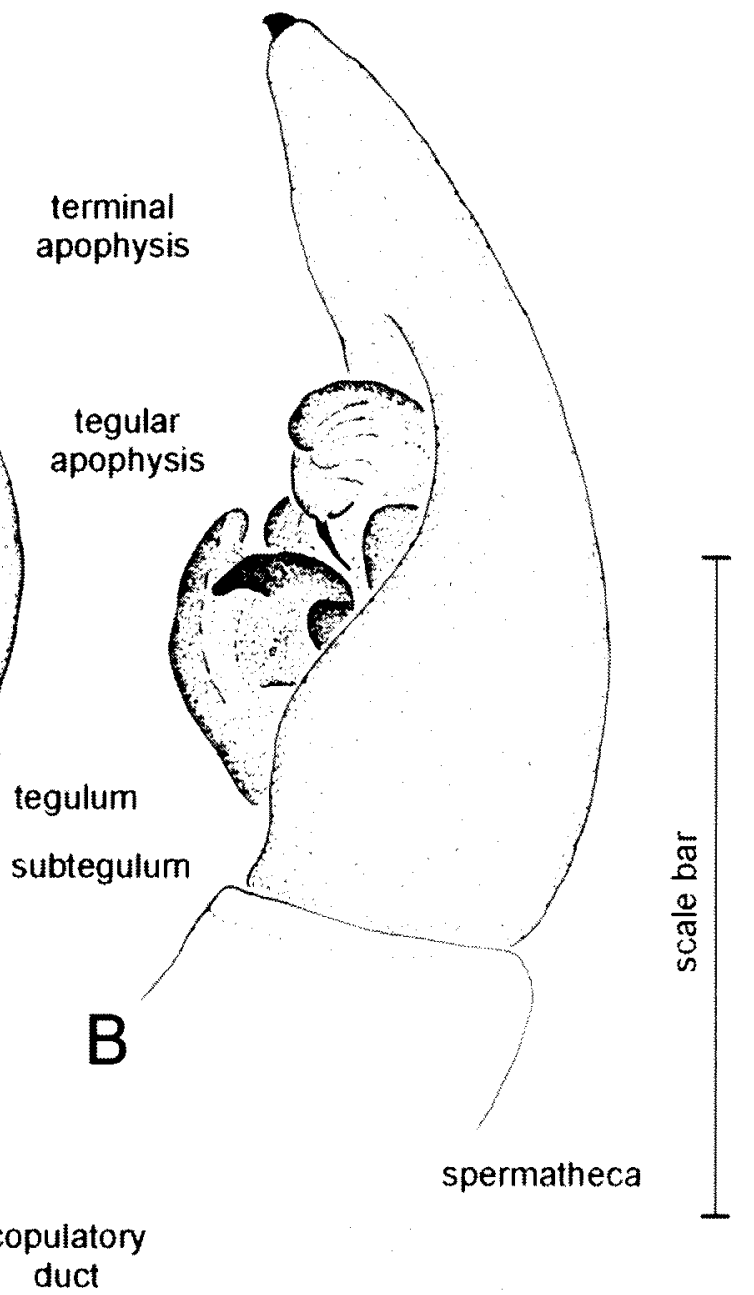

duct
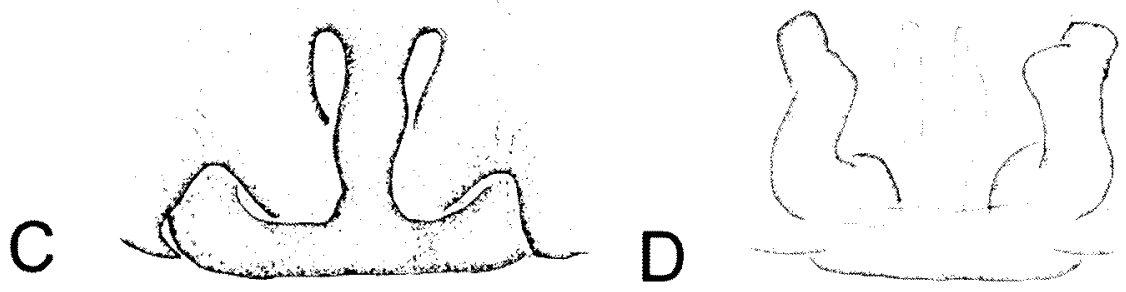

Figure 6 Venatrix kosciuskoensis (McKay, 1974), male (QM S21161 from Falls Creek, Victoria): A, left pedipalp, ventral view; B, left pedipalp, retrolateral view. Female (QM S66444 from Suggan Buggan, Thredbo track, Victoria): C, epigyne, ventral view; D, epigyne, dorsal view. Scale bar: $A, B=1.22 \mathrm{~mm} ; C, D=1.17 \mathrm{~mm}$. 
promarginal teeth, with the middle one largest. Pedipalp (Figures 6A-B): Cymbium tip with small claw-like macrosetae; tegular apophysis forms a large triangle with the retrolateral tip bent ventrally. Abdomen: Dark brown with a distinct light brown median band; brown-black lanceolate patch in anterior half of longitudinal band; laterally a narrow light band along whole carapace; setae black, except in median and lateral bands where they are white. Venter black, with two white spots in posterior half. Spinnerets brown. Legs; Leg formula IV $>$ I $>$ II $>$ III; dorsally brown, ventrally very dark brown; spination of leg I: Femur: 3 dorsal pairs, 2 apicoprolateral; patella: 1 prolateral, 1 retrolateral; tibia: 3 ventral pairs, 1 dorsal, 2 prolateral, 2 retrolateral; metatarsus: 3 ventral pairs, 3 prolateral, 2 retrolateral, 1 apicoventral.

Measurements. TL 9.87, CL 5.92, CW 4.23. Eyes: AME 0.23, ALE 0.18, PME 0.45, PLE 0.38. Row of eyes: AE 1.06, PME 1.13, PLE 1.55. Sternum (length/ width) 2.26/2.07. Labium (length/width) $0.71 / 0.77$. AL 4.42, AW 3.20. Legs: Lengths of segments (femur + patella/tibia + metatarsus + tarsus = total length): Pedipalp 2.16+2.16+ $-+1.60=5.92, \mathrm{I}$ $3.67+4.61+3.20+2.26=13.74$, II $3.57+4.32+3.01+2.07=$ 12.97, III $3.38+3.76+3.20+1.88=12.22$, IV $4.23+4.79+4.70+2.26=15.95$.

Female. See in McKay (1974b). External and internal genitalia of a female from Suggan BugganThredbo track (QM S66444) are depicted here to illustrate diagnostic features (Figures 6C, D).

Variation. A female from Mt Buller, Victoria (QM S66445) lacks the two light ventral spots on the abdomen.

\section{Remarks}

The hitherto unknown male of $V$. kosciuskoensis is described here and although the illustrated specimen was not collected with a female, matching somatic characters, in particular the ventral pattern, and the alpine habitat strongly suggest that the

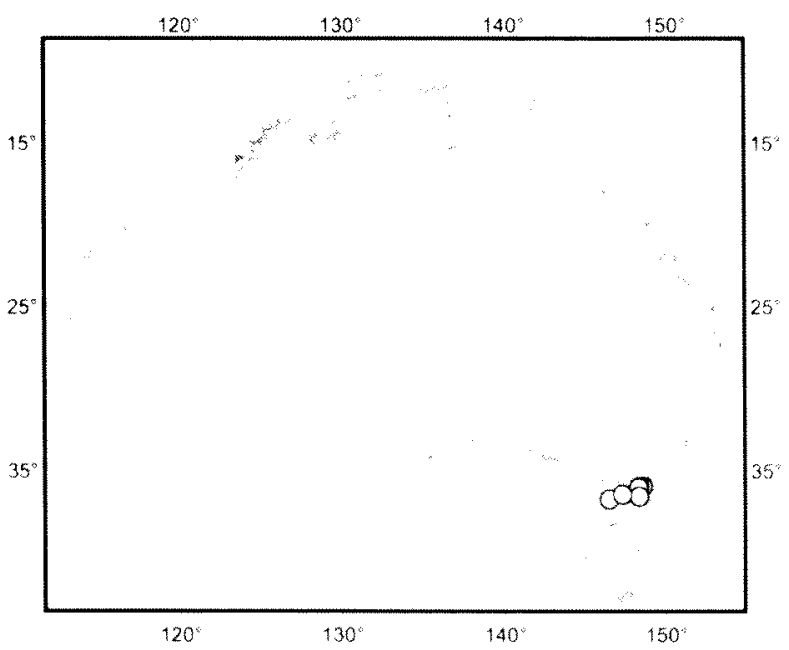

Figure 7 Records of Venatrix kosciuskoensis (McKay 1974). male described here is conspecific with $V$. kosciuskoensis. Male and female genitalia and colouration, and in particular the presence of clawlike macrosetae on the tip of the cymbium and a tubercle on the outer edge of the fangs in males clearly identify $V$. kosciuskoensis as belonging to the genus Venatrix. Consequently, this species is here transferred from the Lycosa to Venatrix.

The original specific epithet is based on "Mt Kosciusko", an anglicisation and former spelling of the highest mountain in Australia. The spelling Mt Kościuszko (original Polish spelling of $T$. Kościuszko after who the mountain was named) was officially adopted only in 1997 by the New South Wales Board of Geographic Names.

\section{Distribution}

New South Wales and Victoria (Figure 7).

\section{Venatrix magkasalubonga (Barrion and Litsinger, 1995), comb. nov. Figures $8 \mathrm{~A}-\mathrm{D}, 9$}

Pardosa magkasalubonga Barrion and Litsinger, 1995: 394-396, figures 235a-h; Platnick 1998: 570.

Pardosa daniloi Barrion and Litsinger, 1995: 398399, fig 237a-h; Platnick 1998: 566. New synonymy.

Pardosa sacayi Barrion and Litsinger, 1995: 399-402, figures 238a-l; Platnick 1998: 575. New synonymy.

Pardosa hawakana Barrion and Litsinger, 1995: 402, figures 239a-j; Platnick 1998: 567. New synonymy.

\section{Types}

Holotype female of Pardosa magkasalubonga, Philippines, Luzon Island, Quezon Province, Real, Llavac Village, $14^{\circ} 26^{\prime} 29^{\prime \prime} \mathrm{N}, 121^{\circ} 26^{\prime} 43^{\prime \prime} \mathrm{E}, 4$ January 1985, A.T. Barrion, M. Perez (IRRI). Examined.

Paratypes of Pardosa magkasalubonga, 2 males, 1 female, data as holotype (IRRI). Examined.

Holotype male of Pardosa daniloi, Philippines, Luzon Island, Laguna Province, Siniloan, Magsaysay Village, $14^{\circ} 26^{\prime} \mathrm{N}, 121^{\circ} 29^{\prime} \mathrm{E}, 18$ July 1984 , A.T. Barrion (IRRI). Not examined.

Paratype male of Pardosa daniloi, data as holotype, labeled "palp on slide \#33" (IRRI). Examined.

Holotype male of Pardosa sacayi, Philippines, Luzon Island, Cagayan Province, Solana, Iriga Village, $13^{\circ} 25^{\prime} 30^{\prime \prime} \mathrm{N}, 123^{\circ} 25^{\prime} 04^{\prime \prime} \mathrm{E}, 28$ July 1980 . A.T. Barrion (IRRI). Examined.

Paratypes of Pardosa sacayi, 2 males, Philippines, Luzon Island, Isabela Province, Alicia, $16^{\circ} 46^{\prime} 41^{\prime \prime} \mathrm{N}$ $121^{\circ} 42^{\prime} 05^{\prime \prime} \mathrm{E}, 23$ October 1981, A.T. Barrion (IRRI). Not examined. 
Holotype male of Pardosa hawakana, Philippines, Mindanao Island, Agusan del Sur, Claveria, Kalingagan, $8^{\circ} 30^{\prime} \mathrm{N}, 125^{\circ} 50^{\prime} \mathrm{E}, 15$ September 1987 , A.T. Barrion (IRRI). Examined.

\section{Diagnosis}

Venatrix magkasalubonga is very similar and keys out to $V$. furcillata in the key to the genus Venatrix (Framenau and Vink 2001) due to the distinct submarginal bands on the carapace. However, males differ in the shape of the tegular apophysis which is apically notched in $V$. furcillata but not in $V$. magkasalubonga. The median septum of the female epigyne of $V$. magkasalubonga does not have the distinct median transverse parts that are present in $V$. furcillata. The species seems to be widespread in rice fields of the Philippines (Figure 9).

\section{Remarks}

The lycosine structure of the male pedipalp (Dondale 1986) in combination with the presence of a tubercle on the outer edge of the fangs in males and a claw-like macroseta on the tip of the cymbium identifies $V$. magkasalubonga as belonging to Venatrix. Consequently, this species is here transferred from Pardosa. The species was recently described in detail (Barrion and Litsinger 1995) and only the pedipalp of one of the paratype males (Figure 8A-B), the epigyne of the holotype female (Figure $8 \mathrm{C}$ ) and the internal genitalia of a paratype female (Figure 8D) are depicted here to illustrate diagnostic features.

I could not find any genitalic or somatic characters that separate Pardosa daniloi Barrion and Litsinger, 1995, Pardosa sacayi Barrion and Litsinger, 1995 and Pardosa hawakana Barrion and

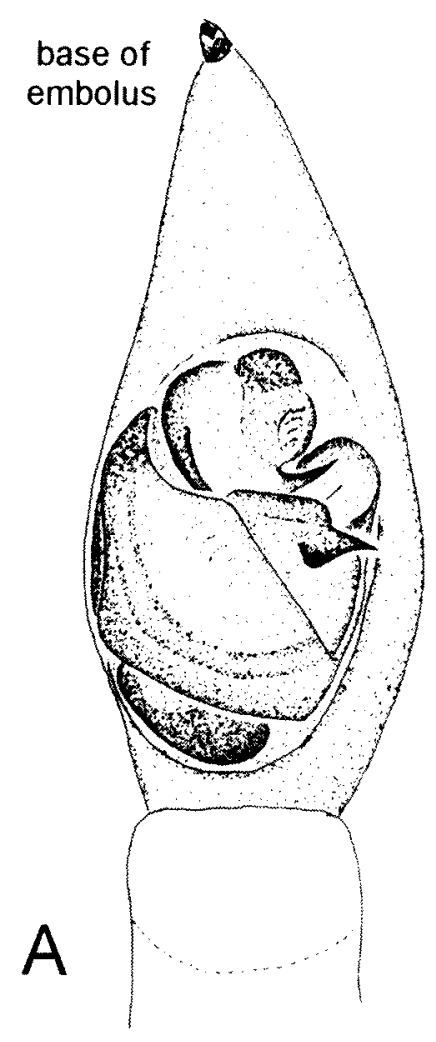

median septum

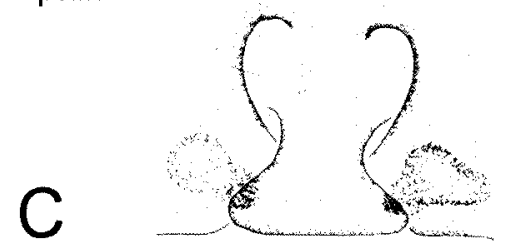

terminal apophysis

tegular apophysis

tegulum subtegulum

B
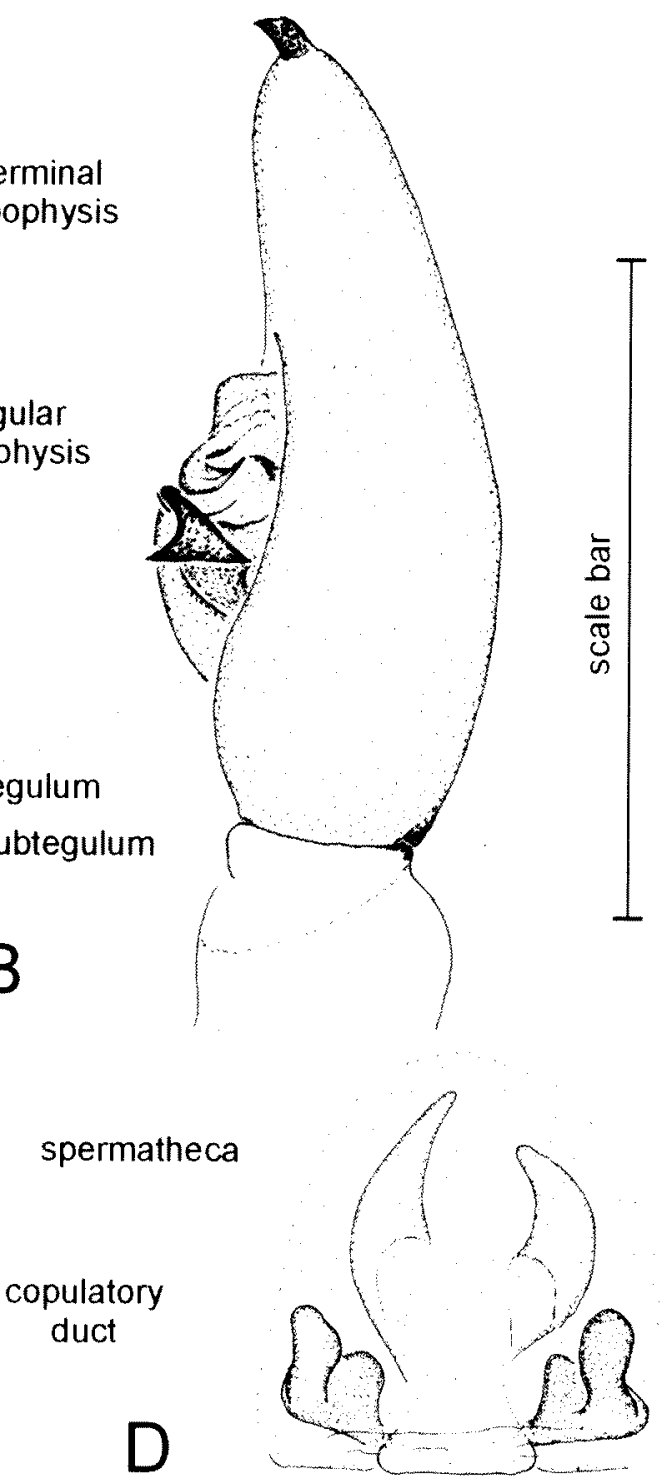

Figure 8 Venatrix magkasalubonga (Barrion and Litsinger, 1905), male paratype (IRRI) from Real, Llavac Village, Phillipines): A, left pedipalp, ventral view; B, left pedipalp, retrolateral view. Female (IRRI, holotype from Real, Llavac Village, Philippines): C, epigyne, ventral view; female (IRRI, paratype from Real, Llavac Village): $\mathrm{D}$, epigyne, dorsal view. Scale bar: $\mathrm{A}, \mathrm{B}=0.84 \mathrm{~mm} ; \mathrm{C}, \mathrm{D}=0.91 \mathrm{~mm}$. 


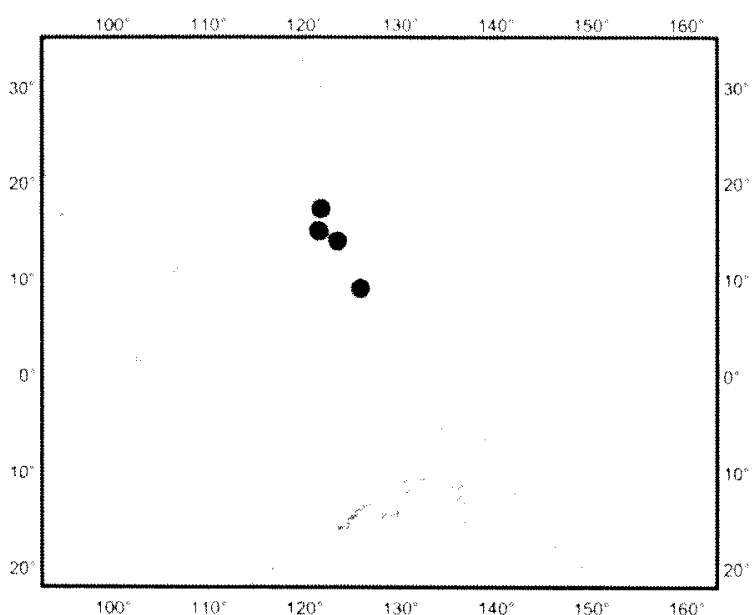

Figure 9 Records of Venatrix magkasalubonga (Barrion and Litsinger 1995).

Litsinger, 1995 from V. magkasalubonga. The pedipalp structure of all males (pedipalps missing in $P$. daniloi, see below) and the epigynes of all females are identical, and the type material of all specimens shows very similar colouration. Barrion and Litsinger (1995) did not provide diagnostic features to separate the species. Consequently, $P$. daniloi, $P$. sacayi and $P$. hawakana are considered junior synonyms of $V$. magkasalubonga.

The holotype of $V$. daniloi could not be located in the collection of the IRRI, and the microscopic slides containing the pedipalps of the paratype male are missing ( $G$. Jahn, personal communication). However, the tubercles on the outer edge of the fangs and somatic characters such as eye arrangement, carapace shape and colouration clearly match the type material of all other species described by Barrion and Litsinger (1995). In addition, the material examined included non-type females of $V$. daniloi from the type locality, which agree with the females of $V$. magkasalubonga.

\section{Venatrix ornatula (L. Koch, 1877) comb. nov.}

Lycosa omatula L. Koch, 1877: 902-903, plate 77, figures 6, 6a-b; Hogg 1900: 76; Rainbow 1911: 270; Bonnet 1957: 2656; McKay 1973: 379; McKay 1985: 81 .

Allocosa ornatula (L. Koch, 1877); Roewer 1955b: 206; Rack 1961: 38.

Venatrix forsteri Framenau and Vink, 2001: 955-956, figures $32 \mathrm{a}-\mathrm{f}, 33$. New synonymy

\section{Types}

Syntype female of Lycosa ornatula, Australia, Queensland, Rockhampton, $150^{\circ} 30^{\prime} \mathrm{E}$, Museum Godeffroy Nr. 14555 (ZMH, Rack (1961) catalog 471). Examined.

Syntype female of Lycosa ornatula, Australia, Queensland, Bowen, 2000'S, $148^{\circ} 14^{\prime} \mathrm{E}$ (BMNH 1919.9.18.712). Examined.
Holotype male of Venatrix forsteri, Australia, Queensland, Berwah Forestry Reserve, 26 51'S, $152^{\circ} 59^{\prime} \mathrm{E}, 31$ October 1990 , pitfall trap, M. Glover, heath (QM S45533). Examined.

Paratypes of Venatrix forsteri, 3 males, 5 females, 10 juv., data as holotype (QM S19146-7, S19151, S19454, S19176, S19178, S19437, S19447). All examined.

\section{Diagnosis}

Venatrix ornatula (as $V$. forsteri) was diagnosed in Framenau and Vink (2001). The species is most similar to $V$. brisbanae, but differs in the carapace colouration. The flanks of the cephalic area and the posterior carapace margin are considerably darker than in $V$. brisbanae. In addition, the tegular apophysis of males of $V$. ornatula only consists of a single part (two distinct parts in $V$. brisbanae) and the median septum of the female epigyne is distinctly wider (Framenau and Vink 2001).

\section{Remarks}

A recent detailed examination of the type material of Lycosa ornatula revealed no differences in somatic and genitalic characters to Venatrix forsteri Framenau and Vink, 2001. Consequently, V. forsteri is considered a junior synonym of $L$. ornatula and the species is transferred from Lycosa to Venatrix.

\section{Venatrix palau sp. nov. Figures 10A-F, 11}

\section{Types}

Holotype male, Palau, Kayangel Atoll, $8^{\circ} 03^{\prime} 50^{\prime \prime} \mathrm{N}$, 134 4200"E, 23 May 1973, J. Berry (BPBM).

Paratypes: 1 male, data as holotype (WAM T62719); 1 female, data as holotype (BPBM).

\section{Diagnosis}

Venatrix palau is very closely related to $V$. amnicola and $V$, arenaris, but can be distinguished by the different colour pattern. The edges of the median band on the carapace are much smoother and do not form a star-shaped pattern in the anterior half. Venatrix palau is also distinctly smaller than $V$. amnicola and $V$, arenaris. In addition, males of all three species can be distinguished by the shape of the terminal apophysis of the pedipalp, which uniquely curves around the tip of the embolus in V. palau.

\section{Etymology}

The species name refers to the type locality of this species, the Palau Islands. It is a noun in apposition.

\section{Other material examined}

Australia: Queensland: 1 male, Aspley Creek, 
Andagrove, Mackay, $21^{\circ} 05^{\prime} \mathrm{S}, 149^{\circ} 12^{\prime} \mathrm{E}, 6$ July 1983 , D.S. Jones, landward salt flat, at margin near land vegetation (WAM T53855); 1 female, Corio Bay, Yeppoon, $23^{\circ} 07^{\prime} \mathrm{S}, 150^{\circ} 44^{\prime} \mathrm{E}$, 6 July 1974, P. Davie, edge of salt march at mangrove edge (QM S66814). Federated States of Micronesia: 1 female, 1 female with eggsac, Yap, Map Island (Cho'ol), 9 $9^{\circ} 35^{\prime} 25^{\prime \prime} \mathrm{N}$, $138^{\circ} 10^{\prime} 12^{\prime \prime} \mathrm{E}, 12$ April 1980, E. Berry (BPBM); 1

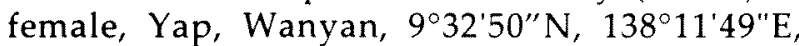
among short beach grass, 17 April 1980, E. Berry (WAM T62721). Palau: 1 female, Kayangel Atoll, $8^{\circ} 03^{\prime} 50^{\prime \prime} \mathrm{N}, 134^{\circ} 42^{\prime} 00^{\prime \prime E}$, May 1973, J.W. Berry, night collecting, coconut forest (BPBM).

\section{Description}

Male (based on holotype, BPBM). Carapace: Light brown with indistinct brown radial pattern; distinct yellow-brown median band, widening slightly behind PLE and then narrowing towards the posterior end; wide yellow-brown submarginal bands; carapace mainly covered with white setae, which are particularly dense in the median and submarginal bands; brown setae in darker parts of carapace in posterior half; two brown bristles behind PLE, one long brown bristle between AME, four long brown bristles below AE. Sternum: Yellow-brown; brown bristles increasing in length towards margins. Labium: Brown, basally darker; front end truncate and white. Chelicerae: Light brown; sparsely covered with brown setae; three retromarginal teeth, with the middle one largest and the apical one shortest; three promarginal teeth, with the middle one largest. Pedipalp (Figures 10AC): Terminal apophysis curves around strong and sickle-shaped embolus (Figure 10C). Abdomen: Yellow-white with guanine crystals shining through the integument; yellow lanceolate heart-mark; mottled brown patches at anterior border of abdomen, as a pair of large spots in the middle of the abdomen and pairs of smaller spots in posterior

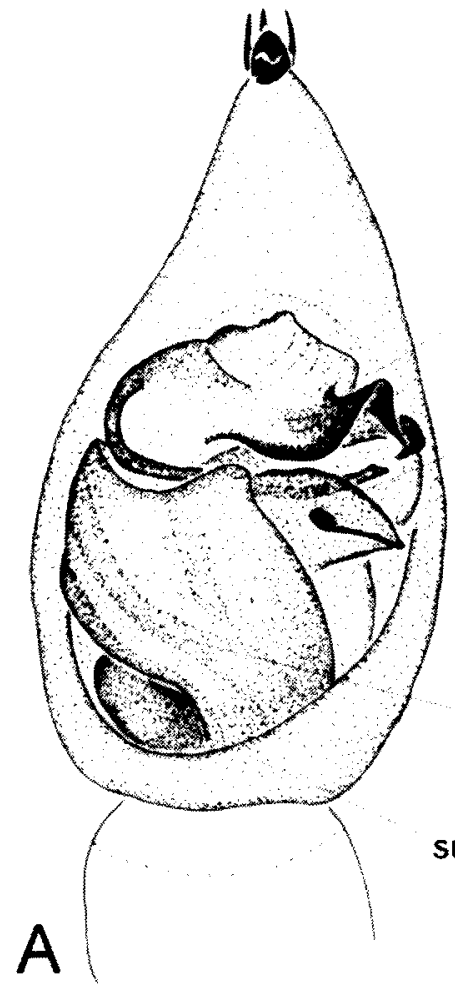

median septum

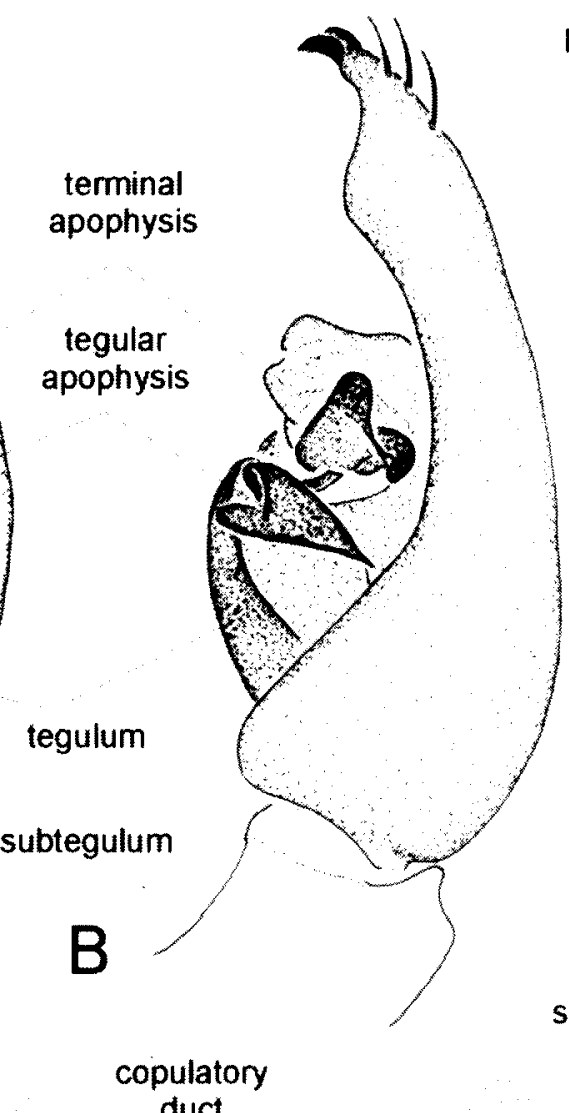

duct
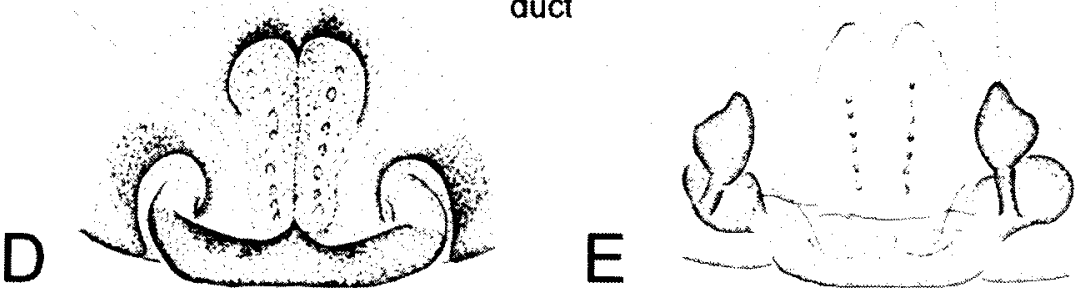

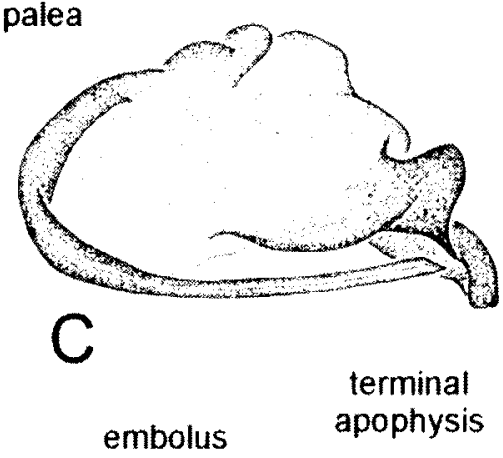

spermatheca

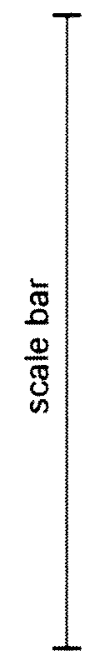

Figure 10 Venatrix palau sp. nov., male (WAM T62719, from Kayangel Atoll, Palau): A, left pedipalp, ventral view; B, left pedipalp, retrolateral view; C, left pedipalp, apical part of bulbus. Female (WAM T62721, from Yap, Wanyan, Federated States of Micronesia): D, epigyne, ventral view; E, epigyne, dorsal view. Scale bar: A, B $=0.78 \mathrm{~mm} ; \mathrm{C}=0.53 \mathrm{~mm} ; \mathrm{D}, \mathrm{E}=0.75 \mathrm{~mm}$. 
half; mainly covered with white setae, except in brown spots where there are brown setae; venter yellow-white (guanine); covered with white and few brown setae; spinnerets yellow-brown. Legs: Leg formula IV > I > II > III; light brown; spination of leg I: femur: 3 dorsal, 3 retrolateral, 1 apicoprolateral; patella: 1 prolateral; tibia: 3 ventral pairs, 2 prolateral, 2 retrolateral; metatarsus: 3 ventral pairs, 3 prolateral, 3 retrolateral, 1 apicoventral.

Female (based on paratype, BPBM). Carapace: As male, but overall darker and the submarginal bands are narrower and not continuous. Sternum: Orangebrown, setae as male. Labium: Dark brown, basally darker; front end truncate and white. Chelicerae: Reddish-brown, setae as male. Epigyne (Figures $10 \mathrm{D}, \mathrm{E})$ : Ventral view: inverted T-shaped (Figure 10D); dorsal view: spermathecae narrowing anteriorly, copulatory ducts narrow and straight, connecting posteriorly to spermathecae (Figure 10E). Abdomen: As male, but generally darker (no guanine) and more brown patches; venter orangebrown, setae as male; spinnerets orange-brown. Legs: Leg formula IV > I > II > III; light brown, femora III and IV with indistinct grey annulations, which are most distinct laterally; spination of leg I: Femur: 3 dorsal, 1 apicoprolateral; tibia: 3 ventral pairs, 2 prolateral; metatarsus: 3 ventral pairs, 1 apicoprolateral, 1 apicoventral.

Measurements. Male holotype, BPBM (female paratype, BPBM): TL 4.98 (6.11), CL 2.82 (2.91), CW 2.07 (1.88). Eyes: AME 0.16 (0.13), ALE $0.09(0.10)$, PME $0.27(0.27)$, PLE $0.22(0.21)$. Row of eyes: AE 0.57 (0.64), PME 0.63 (0.65), PLE $0.82(0.82)$. Sternum (length/width) $1.41 / 1.08$ (1.32/1.13). Labium (length/width) 0.28/0.35 (0.32/0.38). AL 2.26 (3.01), AW 1.50 (2.26). Legs: Lengths of segments (femur + patella/tibia + metatarsus + tarsus $=$ total length): Pedipalp 0.94+1.03+ $++0.95=2.92$, I $2.07+2.44+1.69+1.18=7.38$, II $1.97+2.26+1.55+1.13=$

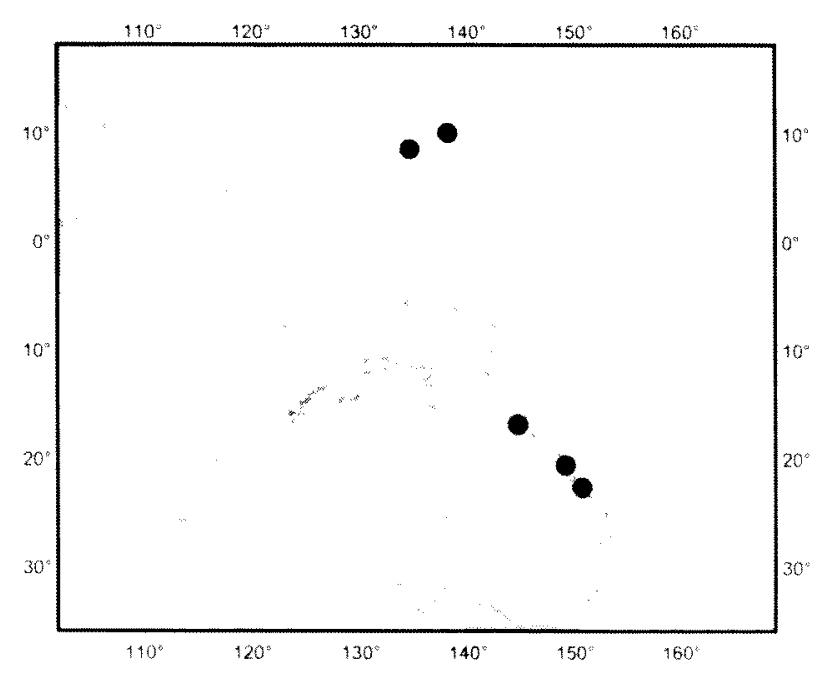

Figure 11 Records of Venatrix palau sp. nov
6.91 , III $1.88+1.97+1.69+0.94=6.48$, IV $2.44+2.82+2.54+1.27=9.07$ (Pedipalp 1.03+1.03+ $+0.75=2.81$, I $1.88+2.16+1.32+0.95=6.31$, II $1.69+2.07+1.27+0.94=5.97$, III $1.65+1.88+1.50+0.85=$ 5.88 , IV $2.21+2.63+2.44+1.13=8.41)$

Variation. Males (females) (range, mean \pm s.d.): TL $4.23-4.98,4.67 \pm 0.39$; Cl $2.44-2.85,2.70 \pm 0.23$; CW $1.69-2.25,1.94 \pm 0.28 ; \mathrm{n}=3$ (TL $5.81-7.14$, $6.39 \pm 0.66$; CL $2.91-3.48,3.12 \pm 0.25$; CW $1.88-$ $2.44,2.18 \pm 0.22 ; n=5$ ). In contrast to the paratype female described above, most other females also show distinct guanine crystals shining through the integument of the abdomen.

\section{Life history and habitat preferences}

This species has only been found sandy habitats, in particular beaches. In Australian it appears to be winter-mature as adults have been found in July. In contrast, spiders from the pacific were collected in April and May.

\section{Distribution}

Queensland, Federated States of Micronesia, and Palau (Figure 11).

\section{Venatrix pullastra (Simon, 1909)}

Lycosa pullastra Simon, 1909: 184-185, figure 2; Rainbow 1911: 272; Bonnet 1957: 2660; McKay 1973: 379; McKay 1974a: 6-12, figures 2a-p;. McKay 1985: 82; Platnick 1993: 488.

Lycosa marcentior Simon, 1909: 185, figure 3; Rainbow 1911: 270; Bonnet 1957: 2652; McKay 1973: 379; McKay 1985: 80; Platnick 1989: 372; Moritz 1992: 319; Platnick 1993: 488. New synonymy.

Lycosa segregis Simon, 1909: 186, figure 4; Rainbow 1911: 272; Bonnet 1957: 2663; McKay 1973: 379; Moritz 1992: 325.

Lycosa propitia Simon, 1909: 186, figure 5; Rainbow 1911: 271; Bonnet 1957: 2659; McKay 1973: 379; McKay 1985: 81; Moritz 1992: 323. New synonymy.

Lycosa percauta Simon, 1909: 187; Rainbow 1911: 271; Bonnet 1957: 2657; McKay 1973: 379; McKay 1985: 81; Moritz 1992: 321. New synonymy.

Allocosa propitia (Simon, 1909); Roewer 1955b: 206; Rack 1961: 38.

Allocosa percauta (Simon, 1909); Roewer 1955b: 206.

Hogna pullastra (Simon, 1909); Roewer 1955b: 253.

Hogna segregis (Simon, 1909); Roewer 1955b: 253.

Hogna marcentior (Simon, 1909); Roewer 1955b: 253. 
not Lycosa marcentior Simon, 1909 sensu McKay 1979b: 263-264, figures 8A-D (misidentification).

Lycosa pallustra Simon, 1909; Moritz 1992: 323 (misspelled).

Venatrix pullastra (Simon); Framenau and Vink 2001: 962-963, figures 42A-D, 43.

\section{Types}

Syntype of Lycosa pullastra, female, Australia, Western Australia, Kings River, $9 \mathrm{mi} \mathrm{N}$ of Albany, $34^{\circ} 52^{\prime} \mathrm{S}, 117^{\circ} 53^{\prime} \mathrm{E}$, 'Hamburger südwest-australische Forschungsreise' Station 164, 17 October 1905, mountainous forest with swamp (ZMB 11099). Examined.

Syntypes of Lycosa pullastra, 1 male, 1 female, labeled 'Austr. occid. (Michaelsen)', most likely (see remarks below): Australia, Western Australia, Mundaring Weir, 30 $04^{\prime} \mathrm{S}, 121^{\circ} 55^{\prime} \mathrm{E}$, 'Hamburger südwest-australische Forschungsreise', Station 101, 9 August 1905, mountainous bushland (MHNP 24355). Examined.

Syntypes of Lycosa marcentior, 1 male, 1 female, labeled 'Swan River (Michaelsen)' (MHNP 24357). Examined.

Syntype female (penultimate) of Lycosa marcentior, labeled 'Australia occid. (Mich.)' (MHNP 24359). Examined.

Syntype female (penultimate) of Lycosa marcentior, Australia, Western Australia, Boyanup, $33^{\circ} 29^{\prime} \mathrm{S}, 115^{\circ} 43^{\prime} \mathrm{E}$, 'Hamburger südwest-australische Forschungsreise', Station 146, 1/3 August 1905, mountainous forest and cultivated landscape (ZMB 11084). Examined.

Syntype immature of Lycosa marcentior, Australia, Western Australia, Dongara, 2915'S, $114^{\circ} 55^{\prime} \mathrm{E}$, 'Hamburger südwest-australische Forschungsreise', Station 84, 17 July 1905, dunebush (ZMH, Rack (1961)-catalogue 466). Examined.

Holotype female of Lycosa segregis, Australia, Western Australia, Fremantle Harbour, $32^{\circ} 03^{\prime} S$, $115^{\circ} 45^{\prime} \mathrm{E}$, 'Hamburger südwest-australische Forschungsreise', Station 37, 17 May 2005, on pylons (ZMB 11101). Examined.

Syntypes of Lycosa propitia, male, penultimate female, labeled 'Austr. occid. (Mich.)', most likely (see remarks below): Australia, Western Australia, Cannington, $32^{\circ} 01^{\prime} \mathrm{S}, 115^{\circ} 56^{\prime} \mathrm{E}$, 'Hamburger südwest-australische Forschungsreise', Station 123, 28 June 1905, swamp with lakes (MHNP 24354). Examined.

Syntype female (penultimate) of Lycosa propitia, Australia, Western Australia, Cannington, $32^{\circ} 01^{\prime} \mathrm{S}$, $115^{\circ} 56^{\prime} \mathrm{E}$, 'Hamburger südwest-australische Forschungsreise', Station 123, 28 June 1905, swamp with lakes (ZMH, Rack (1961)-catalog 475). Examined.

Syntype female (penultimate) of Lycosa propitia, Australia, Western Australia, Cannington, $32^{\circ} 01^{\prime} \mathrm{S}$, $115^{\circ} 56^{\prime} \mathrm{E}$, 'Hamburger südwest-australische Forschungsreise', Station 123, 28 June 1905, swamp with lakes (ZMB 11098). Examined.

Syntype immature of Lycosa propitia, Australia, Western Australia, Cannington, 32 01'S, $115^{\circ} 56^{\prime} \mathrm{E}$, 'Hamburger südwest-australische Forschungsreise', Station 123, swamp with lakes (WAM 11/4302). Examined.

Holotype female of Lycosa percauta, Australia, Western Australia, Rottnest Island, $31^{\circ} 59^{\prime} \mathrm{S}$, $115^{\circ} 32^{\prime} \mathrm{E}$, 'Hamburger südwest-australische Forschungsreise', Station 121, 6/13 October 1905, dense bush with dunes (ZMB 11094). Examined.

\section{Remarks}

Venatrix pullastra was redescribed in detail by McKay (1974a) (herein also synonymised with Lycosa segregis Simon, 1909) and Framenau and Vink (2001). Recent examination of the type material of Lycosa marcentior Simon, 1909, Lycosa propitia Simon, 1909 and Lycosa percauta Simon, 1909 revealed no differences in somatic or genitalic characters to $V$. pullastra. Therefore, all three species are here considered junior synonyms of $V$. pullastra.

The type localities of the syntypes of Lycosa pullastra Simon, 1909 are Mundaring Weir (Station 101) and Kings River, $9 \mathrm{mi} \mathrm{N}$ Albany (Station 164) (Michaelsen and Hartmeyer, 1907; Simon, 1909). Since the syntype in the ZMB is from near Albany, the syntypes in the MHNP, only labeled 'Austr. occid. (Michaelsen)', are almost certainly from Mundaring Weir.

Lycosa marcentior Simon, 1909 was based on material from two localities, Dongara (Station 84), ca. $350 \mathrm{~km}$ north of Perth and Boyanup (Station 146), near Bunbury, ca. $200 \mathrm{~km}$ south of Perth (Michaelsen and Hartmeyer, 1907; Simon, 1909). The only mature specimens of Lycosa marcentior are a male and female lodged at the MHNP labeled 'Swan River (Michaelsen)' without station number or other locality data. Despite the dubious locality data, I consider these specimens part of the syntype series since there were clearly identified as $L$. marcentior by $\mathrm{E}$. Simon and contain the only mature female of which he illustrated the epigyne (Simon 1909). Consequently, McKay's (1979b) redescription of $L$. marcentior, which is based on a different species collected at the type locality Dongara, is erroneous. Apparently, he did not examine the male and female types of this species lodged in the MHNP.

Similarly, the only mature syntype of Lycosa propitia Simon, 1909 is a male (together with a penultimate female) lodged at the MNHP and simply labeled 'Austr. occid. (Mich.)'. Since this species was described only from Cannington (Station 123) (Michaelsen and Hartmeyer 1907; Simon 1909), there is no doubt about the collection data of these specimens. Simon (1909) illustrated 


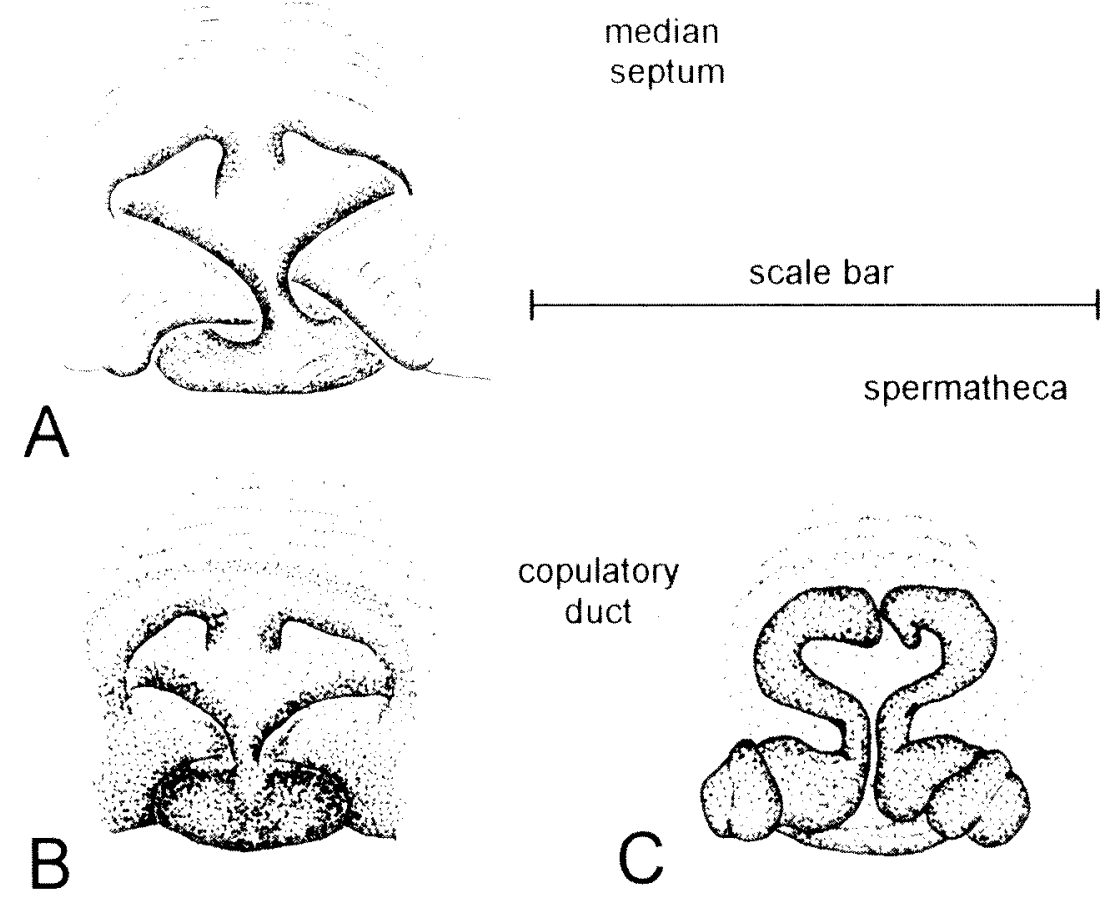

Figure 12 Venatrix summa (McKay, 1974), female holotype (AM KS635, from Mt Kosciuszko, New South Wales): A, epigyne, ventral view; female paratype (AM KS 634, from Mt Kosciuszko, New South Wales): B, epigyne, dorsal view. Scale bar: $A, B, C=0.20 \mathrm{~mm}$.

the epigyne of Lycosa propitia and it appears that this illustration represents a penultimate female. The immature syntype lodged in the $\mathrm{ZMH}$ was mistakenly listed as the holotype by Rack (1961).

Venatrix summa (McKay, 1974) comb. nov. Figures $12 \mathrm{~A}-\mathrm{B}, 13$

Lycosa summa McKay, 1974b: 28-31, figures 1a-c, g-i; Brignoli 1983: 450; McKay 1985: 83-84.

\section{Types}

Holotype female of Lycosa summa McKay, 1974, Australia, New South Wales, Mt Kościuszko, $36^{\circ} 27^{\prime} \mathrm{S}, 148^{\circ} 16^{\circ} \mathrm{E}, 7$ January 1929, A. Musgrave, $\mathrm{H}$. O. Fletcher (AM KS 635). Examined.

Paratypes of Lycosa summa McKay, 1974: 5 females, 9 juv., data as holotype (AM KS633-4, KS 636-8). Examined.

\section{Diagnosis}

Venatrix summa appears to be closely related to $V$. kosciuskoensis, however, females differ in the colouration of carapace and abdomen (McKay 1974 b). In addition, the median septum of the female epigyne in $V$. summa widens anteriorly, whereas it is of similar width along its whole length in V. kosciuskoensis.

\section{Remarks}

When Mckay (1974b) described both $V$. kosciuskoensis and $V$. summa from alpine New South Wales, he suggested that they may be part of the 'arenaris-group', which contained species that have been subsequently transferred to Venatrix (Framenau and Vink 2001). I agree with McKay (1974b), based on the anchor-shaped median septum of the epigyne (Figure 12) and the colour pattern of the abdomen, and transfer this species from Lycosa to Venatrix. The species is only known from the type locality, Mt Kościuszko (Figure 13). The male is unknown.

This species keys out to $V$. roo Framenau and Vink, 2001 or V. australiensis Framenau and Vink, 2001 using the key to the genus Venatrix (Framenau

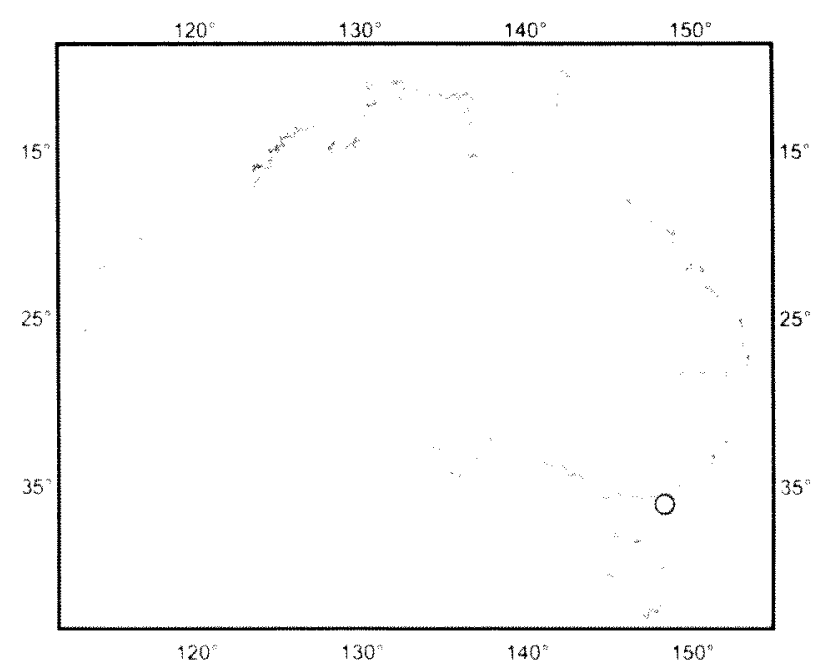

Figure 13 Records of Venatrix summa (MCKay 1974). 
and Vink 2001). However, $V$. summa differs distinctly in the abdominal pattern, which shows a conspicuous dark lanceolate heart mark in a light median band. This lanceolate heart mark is much less conspicuous in the two other species.

Venatrix tinfos sp. nov.

Figures $14 \mathrm{~A}-\mathrm{F}, 15$

\section{Types}

Holotype male, Australia, Western Australia, Lake Bryde West Nature Reserve, Lake Bryde Road, $33^{\circ} 21^{\prime} 40^{\prime \prime S}, 118^{\circ} 48^{\prime} 14^{\prime \prime E}, 15$ October 1999 - 1 February 2000, wet pitfall trap, P. van Heurck et al., CALM Salinity Action Plan, site PI3 (WAM T61661).

Paratypes: 7 males, 3 females, data as holotype (WAM T47210, T47280); 2 females, Australia, west of Scaddan, west of Dalyup Road, $33^{\circ} 23^{\prime} 09^{\prime \prime} S$, $121^{\circ} 34^{\prime} 56^{\prime \prime E}, 15$ October 1999 - 1 November 2000, wet pitfall trap, P. van Heurck et al., CALM Salinity Action Plan, site GP8 (WAM T47276).

\section{Diagnosis}

Venatrix tinfos is very similar to $V$. fontis from South Australia with a similar unusual leg formula of IV $>$ I $>$ III $>$ II, i.e. the third leg is longer than the second leg (all other Venatrix have IV $>$ I $>$ II $>$ III). The male pedipalps of both species are extremely similar. However, the inner edge of the ventral process (see Figure 14A) of the tegular apophysis forms a right angle with the tegular apophysis in $V$. tinfos when viewed from the tip of the cymbium. This angle is distinctly smaller than $90^{\circ}$ in $V$. fontis, i.e. the ventral process appears much more acute. Females can be distinguished by the anchor-shape of the median septum in comparison to the inverted T-shaped median septum of $V$. fontis.

\section{Etymology}

The specific name is an anagram of fontis, as $V$. tinfos is very similar to $V$. fontis.

\section{Other material examined}

Australia: Western Australia: 1 female, Chinocup Reserve, 4 miles E of Pingrup, $33^{\circ} 28^{\prime} \mathrm{S}, 118^{\circ} 26^{\prime} \mathrm{E}, 11$ - 17 February 1972, W. H. Butler (WAM 72/331); 1 male, Coolinup Nature Reserve, 33⒋53's, $122^{\circ} 17^{\prime} 59^{\prime \prime} \mathrm{E}, 15$ October 1999 - 2 May and 29 November 2000, wet pitfall trap, P. van Heurck, CALM Salinity Action Plan, site ES12 (WAM T47272); 1 male, Dead Mans Swamp Nature

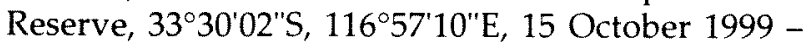
1 November 2000, wet pitfall trap, P. van Heurck et al., CALM Salinity Action Plan, site DA7 (WAM T47278); 2 females, Fitzgerald River (no exact location), 11 July 1970, R. Humphries, J. Gilbert, black soil swamp (WAM 71/492-3); 1 female, Lake
Bryde West Nature Reserve, Lake Bryde Road, $33^{\circ} 21^{\prime} 20^{\prime \prime} \mathrm{S}, 118^{\circ} 54^{\prime} 26^{\prime \prime} \mathrm{E}, 15$ October $1999-1$ November 2000, wet pitfall trap, P. van Heurck et al., CALM Salinity Action Plan, site PI4 (WAM T47273); 18 males, 5 females, near Lort River, North Rollands Road, $33^{\circ} 12^{\prime} 20^{\prime \prime} \mathrm{S}, 121^{\circ} 18^{\prime} 08^{\prime \prime} \mathrm{E}, 15$ October 1999 - 24 May and 26 November 2000, wet pitfall trap, L. King, CALM Salinity Action Plan, site GP7 (WAM T47284); 9 males, 7 females, SW of Scaddan, Speddingup West Road, $W$ of, 33 $30^{\prime} 30^{\prime \prime}$, $121^{\circ} 28^{\prime} 01^{\prime \prime} \mathrm{E}, 15$ October 1999 - 1 November 2000, wet pitfall trap, P. van Heurck et al., CALM Salinity Action Plan, site GP10 (WAM T47275, T47283); 1 female, $\mathrm{W}$ of Scaddan, $\mathrm{N}$ of South Griffiths Road, $33^{\circ} 27^{\prime} 13^{\prime \prime} \mathrm{S}, 121^{\circ} 15^{\circ} 01^{\prime \prime} \mathrm{E}, 15$ October 1999 - 1 November 2000, wet pitfall trap, P. van Heurck et al., CALM Salinity Action Plan, site GP11 (WAM T47281)

\section{Description}

Male (based on holotype, WAM T62661). Carapace: Brown with darker margins and indistinct darker radial pattern; narrow light brown median band; covered with black setae, but white setae in median band and between PE; black bristles lateral of PE, one long brown bristle between AME, four long brown bristles below AE. Sternum: Light brown; brown bristles increasing in length towards margins. Labium: Brown; front end truncate and white. Chelicerae: Brown; covered with silver-white setae, a few black setae medially; three promarginal teeth with the median one largest, two retromarginal teeth of similar size. Pedipalp (Figures 14A-C): Lateral tip of tegular apophysis pointing basally, terminal apophysis and embolus sickle-shaped, pars pendula very broad (Figure 14C). Abdomen: Dark olive-grey and covered with black setae; indistinct light median band in which guanine crystals shine through anteriorly and medially; indistinct brown-grey heart mark in anterior half; median band and heart mark covered with silver-grey setae; venter grey-brown, covered with short brown setae; spinnerets brown. Legs: Leg formula IV $>$ I $>$ III $>$ II; light brown, with indistinct darker annulations; apical segments somewhat darker; spination of leg I: Femur: 3 dorsal, 3 dorsolateral, 2 apicoprolateral; patella: 1 prolateral, 1 retrolateral; tibia: 3 ventral pairs, 2 prolateral, 2 retrolateral; metatarsus: 3 ventral pairs, 2 prolateral, 1 retrolateral, 1 apicoventral, 1 apicoprolateral, 1 apicoretrolateral.

Female (based on WAM T47276). Carapace: As male, some white setae in brown areas. Sternum: Light brown, with dark grey pigmentation, setae as male. Labium: Dark brown, front end truncate and white. Chelicerae: Dark reddish-brown, setae and dentition as male. Epigyne (Figures 14D, E): Ventral view: Medium septum inverted anchor-shaped (Figure 14D); dorsal view: short copulatory ducts, 


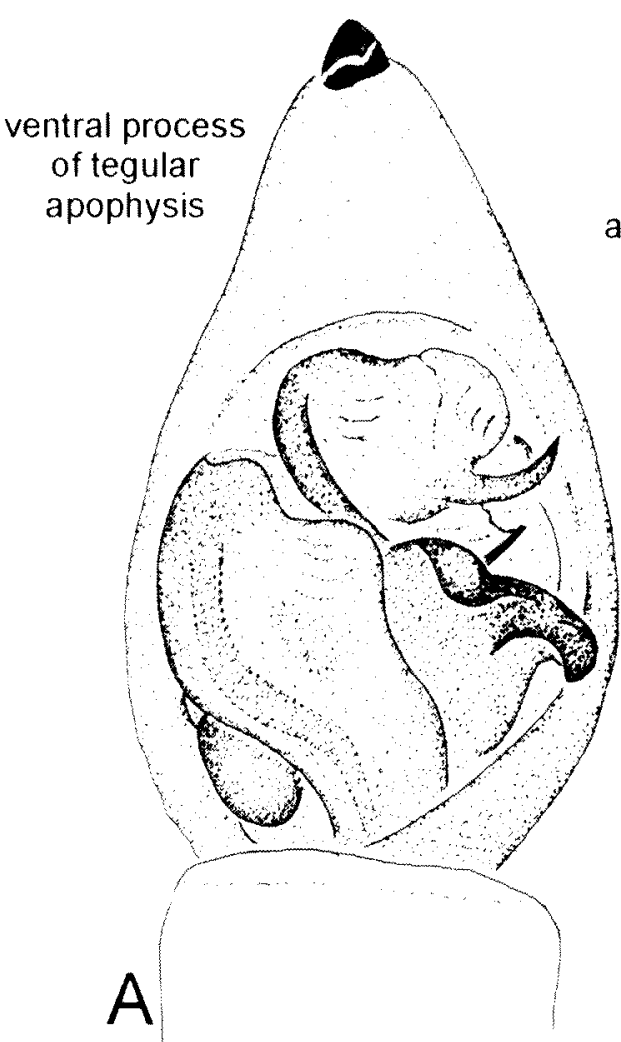

median septum terminal

apophysis

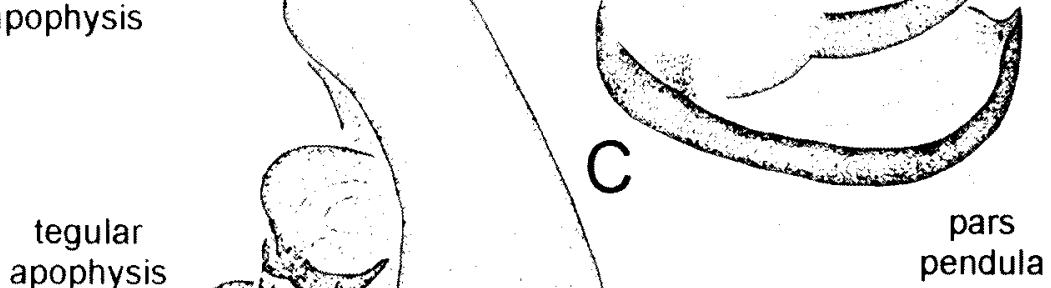

embolus

ophysis

terminal apophysis

B

tegulum

subtegulum

B

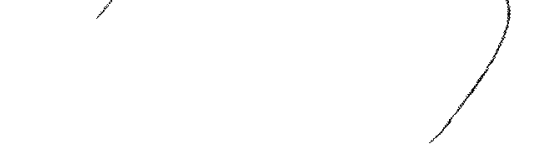

spermatheca

copulatory
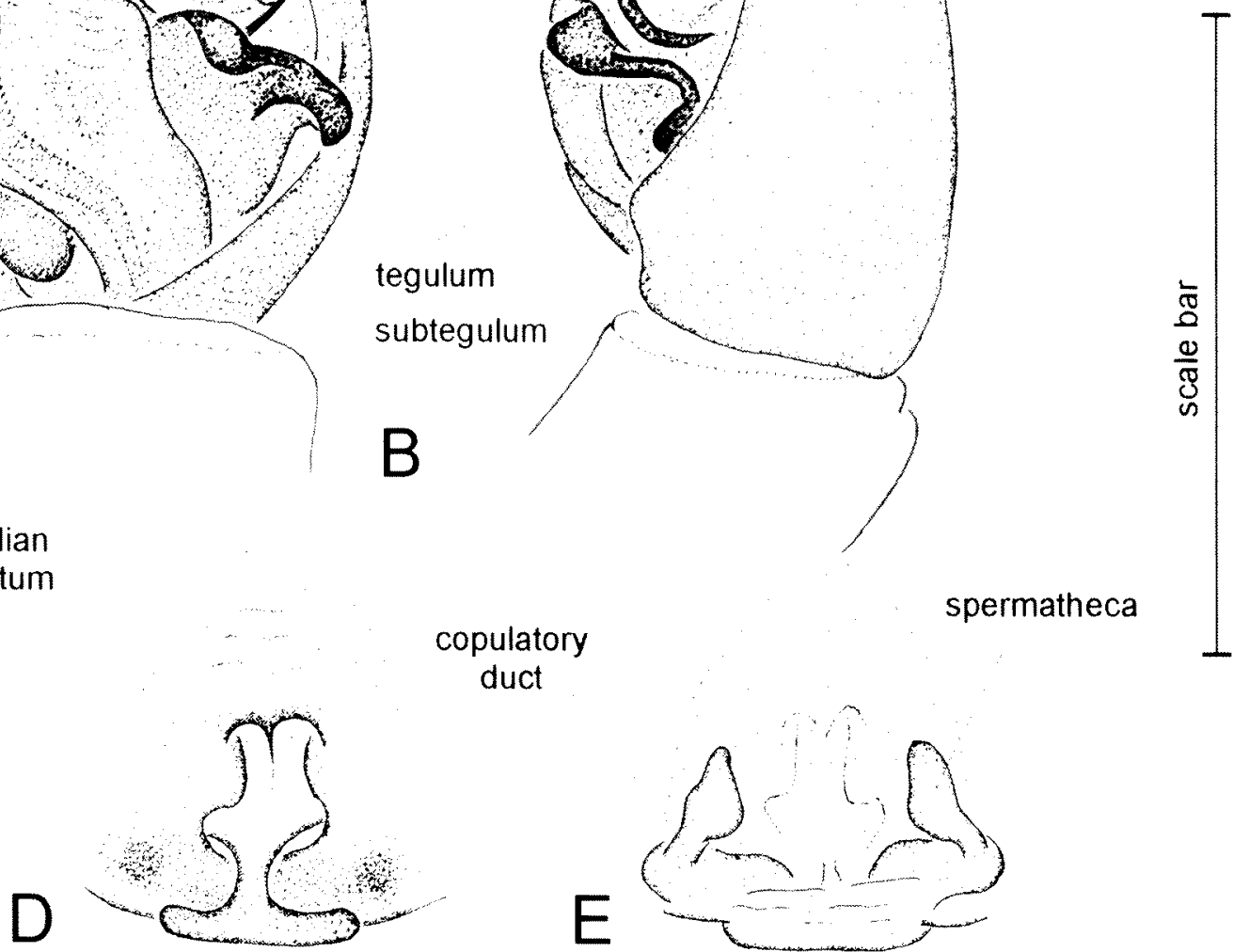

duct

Figure 14 Venatrix tinfos sp. nov, male (WAM T61661 from Lake Bryde West Nature Reserve, Western Australia): A, left pedipalp, ventral view; B, left pedipalp, retrolateral view; C, left pedipalp, apical part of bulbus. Female (WAM T47276 from West of Scadden, Western Australia): D, epigyne, ventral view; E, epigyne, dorsal view. Scale bar: $\mathrm{A}, \mathrm{B}=1.08 \mathrm{~mm} ; \mathrm{C}=0.40 \mathrm{~mm} ; \mathrm{D}, \mathrm{E}=0.91 \mathrm{~mm}$.

elongated spermathecae (Figure 14E). Abdomen: Light brown with grey pigmentation, pattern as male but less distinct; venter yellow-brown, short brown setae; spinnerets yellow-brown. Legs: Leg formula IV > I > III > II; colouration as male, but annulations very indistinct; spination of leg $\mathrm{I}$ : Femur: 2 dorsal, 2 apicoprolateral; tibia: 3 ventral pairs, 1 prolateral (only on left leg); metatarsus: 3 ventral pairs, 1 apicoventral.

Measurements. Male holotype, WAM T62661 (female, WAM T47276): TL 8.20 (8.84), CL 4.32 (4.04), CW 3.29 (2.63). Eyes: AME 0.19 (0.15), ALE $0.12(0.09)$, PME $0.87(0.30)$, PLE $0.27(0.25)$. Row of eyes: AE 0.77 (0.67), PME 0.87 (0.72), PLE 1.16
(1.00). Sternum (length/width) $1.97 / 1.50$ (1.60/1.22). Labium (length/width) $0.64 / 0.60(0.56 / 0.55)$. AL 3.48 (5.36), AW 2.16 (2.82). Legs: Lengths of segments (femur + patella/tibia + metatarsus + tarsus $=$ total length): Pedipalp 1.77+1.69+ $++1.32=4.78, \mathrm{I}$ $3.10+3.95+2.73+1.88=11.66$, II $2.91+3.67+2.07+1.69=$ 10.34 , III $2.82+3.29+2.73+1.60=10.44$, IV $3.57+4.51+3.85+2.07=14.00$ (Pedipalp $1.22+1.22+$ $+0.85=3.29$, I $2.26+2.91+1.69+1.08=7.94$, II $2.16+2.73+1.60+1.03=7.52$, III $2.26+2.54+1.79+1.03=$ 7.62, IV $2.73+3.76+3.01+1.32=10.82)$.

Variation. Males (females) (range, mean \pm s.d.): TL $7.50-10.20,8.50 \pm 0.86 ;$ CL $4.35-5.85,4.88 \pm$ $0.44 ; \mathrm{CW} 3.30-4.50,3.78 \pm 0.33 ; \mathrm{n}=11$ (TL $8.70-$ 
$16.65,11.76 \pm 2.66 ; \mathrm{CL} 4.05-7.50,5.39 \pm 1.11 ; \mathrm{CW}$ $3.00-6.00,4.20 \pm 1.01 ; \mathrm{n}=12$ ).

\section{Life history and habitat preferences}

The majority of the specimens of $V$. fontis were collected during a survey of the Western Australian agricultural zone conducted by the Department of Conservation and Land Management (CALM) (e.g., Keighery 2004; Harvey et al. 2004). The long opening periods of the pitfall traps do not allow an interpretation of the life cycle of this species. Venatrix tinfos was taken in open, moderately moist habitats.

\section{Remarks}

The male of $V$. tinfos keys out to $V$. fontis and the female to $V$. pullastra using the identification key to the species of Venatrix in Framenau and Vink (2001). Males can be distinguished using the diagnosis above, whereas females clearly differ in their leg formula.

\section{Distribution}

Southwestern Western Australia (Figure 15).

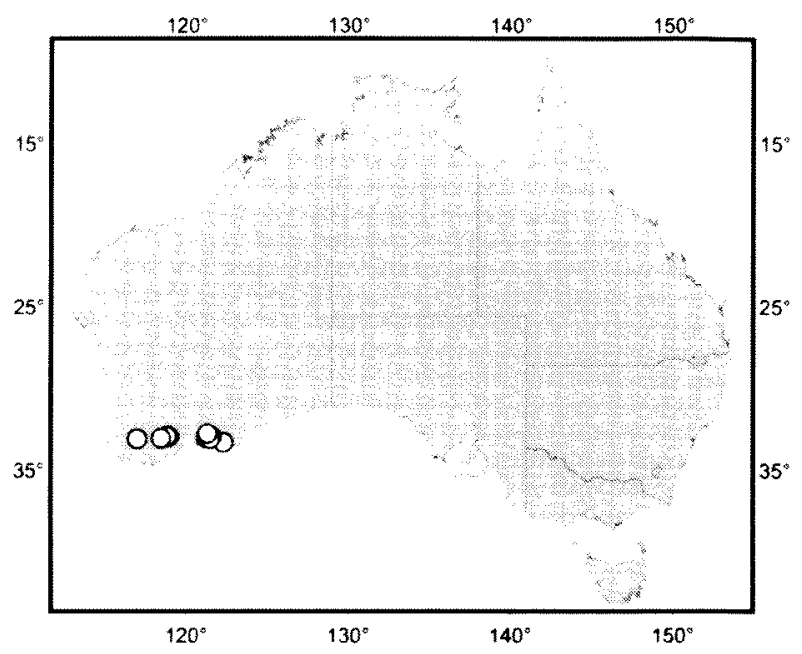

Figure 15 Records of Venatrix tinfos sp. nov.

\section{ACKNOWLEDGEMENTS}

I am grateful to the staff of all the museums who provided access to their collections in the form of loans or while visiting their institutions: Graham Milledge and Mike Gray (AM), Bruce Halliday (ANIC), Janet Beccaloni (BMNH), Pascal Leblanc

Table 1 Distribution of all species of the genus Venatrix. Species treated in this study are indicated with an asterisk $\left({ }^{*}\right)$. For abbreviations of Australian states, see 'Methods'.

\begin{tabular}{|c|c|}
\hline Species & Distribution \\
\hline Venatrix allopictiventris Framenau and Vink, 2001 & NSW, QLD \\
\hline${ }^{*}$ Venatrix amnicola sp. nov. & NSW, QLD, VIC (Figure 3) \\
\hline${ }^{*}$ Venatrix archookoora Framenau and Vink, 2001 & QLD (Figure 5) \\
\hline Venatrix arenaris $(\mathrm{Hogg}, 1905)$ & NSW, NT, QLD, SA, WA \\
\hline Venatrix australiensis Framenau and Vink, 2001 & NSW, QLD \\
\hline${ }^{*}$ Venatrix brisbanae (L. Koch, 1878) & NSW, QLD \\
\hline Venatrix esposica Framenau and Vink, 2001 & $\mathrm{NSW}^{1}, \mathrm{SA}, \mathrm{TAS}, \mathrm{VIC}, \mathrm{NT}^{2}$ \\
\hline Venatrix fontis Framenau and Vink, 2001 & NSW' ${ }^{1}$, SA, VIC \\
\hline Venatrix funesta (C. L. Koch, 1847) & ACT, NSW, SA, TAS, VIC \\
\hline${ }^{*}$ Venatrix furcillata (L. Koch, 1867) & NSW, QLD, TAS', VIC \\
\hline Venatrix hickmani Framenau and Vink, 2001 & NSW, QLD \\
\hline *Venatrix konei (Berland, 1924) & NSW, NT, QLD, SA, VIC, WA, New Caledonia', New Zealand \\
\hline Venatrix koori Framenau and Vink, 2001 & VIC \\
\hline${ }^{*}$ Venatrix kosciuskoensis (McKay, 1974) & NSW, VIC (Figure 7) \\
\hline Venatrix lapidosa (McKay, 1974) & NSW, QLD, VIC \\
\hline${ }^{*}$ Venatrix magkasalubonga (Barrion and Litsinger, 1995) & Philippines (Figure 9) \\
\hline Venatrix mckayi Framenau and Vink, 2001 & ACT, NSW, VIC \\
\hline${ }^{*}$ Venatrix ornatula (L. Koch, 1877) & NSW, QLD \\
\hline${ }^{*}$ Venatrix palau sp. nov. & QLD, Micronesia, Palau (Figure 11) \\
\hline Venatrix penola Framenau and Vink, 2001 & SA, VIC \\
\hline Venatrix pictiventris (L. Koch, 1877) & ACT, NSW, QLD, SA, TAS, VIC \\
\hline Venatrix pseudospeciosa Framenau and Vink, 2001 & ACT, NSW, SA, TAS, VIC \\
\hline${ }^{*}$ Venatrix pullastra (Simon, 1909) & WA \\
\hline Venatrix roo Framenau and Vink, 2001 & $\mathrm{SA}$ \\
\hline Venatrix speciosa (L. Koch, 1877) & ACT, NSW, QLD, SA, VIC \\
\hline${ }^{*}$ Venatrix summa (McKay, 1974) & NSW (Figure 13) \\
\hline${ }^{*}$ Venatrix tinfos sp. nov. & WA (Figure 15) \\
\hline
\end{tabular}

\footnotetext{
1 Range extension on state or country level in comparison to Framenau and Vink (2001)
}

2 Single, record outside the normal range of the species. 
(MNHT), Ken Walker, Peter Lillywhite and Richard Marchant (MV), Owen Seeman and Robert Raven (QM), David Hirst (SAM), Mark Harvey and Julianne Waldock (WAM), Jason Dunlop and Shahin Nawai (ZMB), Josie Catindig and Gary Jahn (IRRI), Gavin Dally (NTMAG), and Hieronymus Dastych (ZMH). I am in particular grateful to Tracey Churchill (Darwin) and Barbara Baehr and Robert Raven (Brisbane) for their hospitality during recent visits to the NTMAG and QM and to James $W$. Berry for sending me his collection of Pacific Island lycosids for systematic studies. Julianne Waldock, Melissa Thomas, Mark Harvey and Robert Raven provided helpful comments on earlier drafts of this manuscript.

This study forms part of a revision of Australian wolf spiders funded by the Australian Biological Resources Study (ABRS) to M. Harvey (Western Australian Museum) and A. Austin (The University of Adelaide).

\section{REFERENCES}

Barrion, A.T. and Litsinger, J.A. (1995). Riceland Spiders of South and Southeast Asia. CAB International, Wallingford, pp. 1-736.

Berland, L. (1924). Araignées de la Nouvelle-Calédonie et des Îles Loyalty. Nova Caledonia Zoologie 3: 159-255.

Berland, L. (1938). Araignées des Nouvelles-Hébrides. Annales de la Société Entomologique de France 107: 121-190.

Bonnet, P. (1957). Bibliographia Araneorum, Tome II (3 ${ }^{\text {mi }}$ partie: G-M), Douladoure, Toulouse, pp. 1926-3026

Brignoli, P.M. (1983). A Catalogue of the Araneae described between 1940 and 1981. Manchester University Press in association with The British Arachnological Society, Butler and Tanner Ltd, Frome and London. 755pp.

Dondale, C.D. (1986). The subfamilies of wolf spiders (Araneae: Lycosidae). Actas $X$ Congreso Internacional de Aracnología, Jaca, España 1: 327-332.

Framenau, W.W. (1998). Life cycles of Lycosa lapidosa McKay, 1974, and Lycosa arenaris (Hogg, 1905), two riparian wolf spiders from south-eastern Australia. In P. A. Selden (ed.) Proceedings of the $17^{\text {h }}$ European Colloquium of Arachnology, Edinburgh 1997. pp. 227-234 Burnhem Beeches, Bucks.

Framenau, V.W. (2002a). Review of the wolf spider genus Artoria Thorell (Araneae: Lycosidae). Invertebrate Systematics 16: 209-235.

Framenau, V.W. (2002b). Taxonomy, Life History Characteristics, and Ecology of Riparian Wolt Spiders (Araneae, Lycosidae) in the Victorian Alps, South-east Australia. Ph.D. thesis, The University of Melbourne, $237 \mathrm{pp}$.

Framenau, V.W. (2005). The wolf spider genus Artoria Thorell in Australia: new synonymies and generic transfers (Araneae, Lycosidae). Records of the Western Australian Museum 22: 265-292

Framenau, V.W. (in press). Mainosa, a new genus for the Australian 'Shuttlecock Wolf Spider' (Araneae, Lycosidae). Journal of Arachnology.
Framenau, V.W. and C.J. Vink (2001). Revision of the wolf spider genus Venatrix Roewer (Araneae: Lycosidae). Invertebrate Taxonomy 15: 927-970.

Framenau, V.W., Manderbach, R. and Baehr, M. (2002). Riparian gravel banks of upland and lowland rivers in Victoria (south-east Australia): arthropod community structure and life-history patterns along a longitudinal gradient. Australian Joumal of Zoology 50: $103-123$

Framenau, V.W., Gotch, T.B. and Austin, A.D. (in press). The wolf spiders of artesian springs in arid South Australia, with a revalidation of Tetralycosa (Araneae, Lycosidae). Journal of Arachnology.

Framenau, V.W. and Yoo, J.-C. (in press). Systematics of the new Australian wolf spider genus Tuberculosa (Araneae, Lycosidae). Invertebrate Systematics.

Gotch, T.B. 2003. The dispersal, colonization and genetic variation of mound spring lycosids. Australasian Arachnology 66: 8-14.

Harvey, M.S., Waldock, J.M., Guthrie, N.A., Durrant, B.J. and McKenzie, N.L. (2004). Patterns in the composition of ground-dwelling araneomorph spider communities in the Western Australian wheatbelt. In G. J. Keighery, S. A. Halse, M. S. Harvey and N. L. McKenzie (eds), A Biodiversity Survey of the Western Australian Agricultural Zone. Records of the Western Australian Museum, Supplement 67: 257-292.

Hickman, V.V. (1944). The Simpson Desert Expedition, 1939 - Scientific Reports No. 1, Biology - Scorpions and Spiders. Transactions of the Royal Society of South Australia 68: 18-48.

Hogg, H.R. (1896). Araneidae. In B. Spencer (ed.) Report of the Horn Expedition to Central Australia. Pt. 2. Zoology. pp. 309-356. Melville, Mullen and Slade, Melbourne.

Hogg, H.R. (1900). A contribution to our knowledge of the spiders of Victoria; including some new species and genera. Proceedings of the Royal Society of Victoria 8: 67-123.

Hogg, H.R. (1905). On some South Australian spiders of the family Lycosidae. Proceedings of the Zoological Society London 1905: 569-590.

Keighery, G.J. (2004). State salinity strategy biological survey of the Western Australian wheatbelt: background In G. J. Keighery, S. A. Halse, M. S. Harvey and N. L. McKenzie (eds) A Biodiversity Survey of the Western Australian Agricultural Zone. Records of the Western Australian Museum, Supplement 67: 1-6.

Koch, C.L. (1847). Die Arachniden. 14. Band. Zeh'sche Buchhandlung, Nurnberg.

Koch, L. (1867). Beschreibung neuer Arachniden und Myriapoden. Verhandlungen der kaiserlich-königlich zoologisch-botanischen Gesellschaft in Wien 17: 173250 .

Koch, L. (1876). Die Arachniden Australiens, nach der Natur beschrieben und abgebildet. Bauer and Raspe, Nürnberg, pp. 741-888.

Koch, L. (1877). Die Arachniden Australiens, nach der Natur beschrieben und abgebildet. Bauer and Raspe, Nürnberg, pp. 889-968.

Koch, L. (1878). Die Arachniden Australiens, nach der 
Natur beschrieben und abgebildet. Bauer and Raspe, Nürnberg, pp. 969-1044.

Latreille P.A. (1804). Tableau méthodique des insects. Noveau Dictionnaire d'Histoire Naturelle Paris 24, 129-295.

McKay, R.J. (1973). The wolf spiders of Australia (Araneae: Lycosidae): 1. The bicolor group. Memoirs of the Queensland Museum 16: 375-398.

McKay, R.J. (1974a). The wolf spiders of Australia (Araneae: Lycosidae): 2 . The arenaris group. Memoirs of the Queensland Museum 17: 1-19.

McKay, R.J. (1974b). The wolf spiders of Australia (Araneae: Lycosidae): 4. Three new species from Mount Kosciusko, N.S.W. Memoirs of the Queensland Museum 17: 27-36.

McKay, R.J. (1979a). The wolf spiders of Australia (Araneae: Lycosidae): 11. A new species from Lord Howe Island. Memoirs of the Queensland Museum 19: $237-240$.

McKay, R.J. (1979b). The wolf spiders of Australia (Araneae: Lycosidae): 12. Descriptions of some Western Australian species. Memoirs of the Queensland Museum 19: 241-275.

McKay, R.J. (1985). Lycosidae. In D. W. Walton (ed.) Zoological Catalogue of Australia, Vol. 3. Arachnida, Mygalomorphae, Araneomorphae in Part, Pseudoscorpionida, Amblypygida, Palpigradi. pp. 73-88. Australian Government Publishing Service, Canberra.

Michaelsen, W. and Hartmeyer, R. (1907). Reisebericht. In W. Michaelsen and R. Hartmeyer (eds) Die Fauna Südwest-Australiens. Ergebnisse der Hamburger südwest-australischen Forschungsreise 1905. pp. 1116. Gustav Fischer, Jena

Moritz, M. (1992). Die Typen der Arachniden-Sammlung des Zoologischen Museums Berlin. X. Araneae: Lycosidae. Mitteilungen des Zoologischen Museums Berlin 68: 309-329.

Murphy, N.P., Framenau, V.W., Donellan, S.C., Harvey, M.S., Park, Y.C. and Austin, A.D. (in press). Phylogenetic reconstruction of the wolf spiders (Araneae, Lycosidae) using sequences from 12S rRNA, 28S rRNA and NADH1 genes: implications for classification, biogeography and the evolution of webbuilding behavior. Molecular Phylogenetics and Evolution.

Platnick, N.I. (1989). Advances in Spider Taxonomy, 1981-1987. Manchester University Press, Manchester, $673 \mathrm{pp}$.

Platnick, N.I. (1993). Advances in Spider Taxonomy, 1988-1991. With Synonymies and Transfers 19401980. New York Entomological Society in association with the American Museum of Natural History, New York, 846 pp.
Platnick, N.I. (1998) [imprint date 1997]. Advances in Spider Taxonomy, 1992-1995. With Redescriptions 1940-1980. New York Entomological Society in association with the American Museum of Natural History, New York, $976 \mathrm{pp}$.

Platnick, N.I. (2005). The World Spider Catalog, Version $5.5 \mathrm{http} / /$ research.amnh.org/entomology/spiders/ catalog/INTRO1.html. American Museum of Natural History.

Rack, G. (1961). Die Entomologischen Sammlungen des Zoologischen Staatsinstituts und Zoologischen Museums Hamburg. II. Teil Chelicerata II: Araneae. Mitteilungen des Hamburgischen Zoologischen Museums und Instituts 59: 1-60.

Rainbow, W.J. (1911). A census of Australian Araneidae. Records of the Australian Museum 9: 107-319.

Roewer, C.F. (1955a). Die Araneen der Österreichischen Iran-Expedition 1949/50. Sitzungsberichte der Österreichischen Akademie der Wissenschaften. Mathematisch-naturwissenschaftliche Klasse $\mathbf{1 6 4}$ $751-782$

Roewer, C.F. (1955b) [imprint date 1954]. Katalog der Araneae von 1758 bis 1940. Vol. 2a. pp. 1-923. Institut Royal des Sciences Naturelles de Belgique, Bruxelles.

Roewer, C.F. (1959). Araneae Lycosiformae II (Lycosidae). Exploration du Parc National de l'Upemba-Mission GF de Witte 55: 1-518.

Roewer, C.F. (1960) [imprint date 1959]. Araneae Lycosiformae II (Lycosidae) (Fortsetzung und Schluss). Exploration du Parc National de I'Upemba Mission GF de Witte 55: 519-1040.

Simon, E. (1909). Araneae, 2 me partie. In W. Michaelson and R. Hartmeyer (eds) Die Fauna SüdwestAustraliens. Ergebnisse der Hamburger südwestaustralischen Forschungsreise 1905. pp. 155-212. Gustav Fischer, Jena.

Sundevall, J.C. (1833). Conspectus Arachnidum. C. F. Berling, Lund (Sweden), 1-39.

Thorell, T. (1877). Studi sui Ragni Malési e Papuani. Annali di Museo Civico di Storia Naturale 'Giacomo Doria', Genova 10: 341-634.

Vink, C.J. (2002). Fauna of New Zealand. Number 44. Lycosidae (Arachnida: Araneae). Manaaki Whenua Press, Lincoln (New Zealand), pp. 1-94.

Zyuzin, A.A. and Logunov, D.V. (2000). New and littleknown species of the Lycosidae from Azerbaijan, the Caucasus (Araneae, Lycosidae). Bulletin of the British arachnological Society 11: 305-319.

Manuscript received 29 April 2005; accepted 23 October 2005. 